\title{
China's Extraordinary Population Expansion and Its Determinants during the Qing Period, 1644-1911
}

\author{
Kent Deng \\ London School of Economics, UK \\ Sun Shengmin \\ Shandong University, China
}

I. Introduction, motivations and data

It is commonly agreed that pre-modern China's population experienced two growth spurts: one in the tenth to eleventh centuries (Northern Song: 960-1127), and other during c. 1700-1830 (Qing: 1644-1911). ${ }^{1}$ During the first growth spurt, China's population jumped from about 50 to 120 million before declining; during the second population rose dramatically from about 56 to 400 million before again declining. ${ }^{2}$ Taken together, these two growth spurts accounted for only about 10 percent of the total lifespan of the Chinese empire (2,132 years, $221 \mathrm{BC}-1911)$. Thus, they were exceptions rather than the rule in China's long-term historiography.

During the Song spurt, the annual population growth rate was 1.07 percent; under the Qing, it was substantially higher, at 1.50 percent. Not only was the Qing population growth rate 40 percent greater than that of the Song, but the growth also proved to be

\footnotetext{
1 Many scholars have backdated the second spurt c. 1500; e.g. Ping-ti Ho, Studies on the Population of China, 13681953 (Cambridge [Mass.]: Harvard University Press, 1959); D. H. Perkins, Agricultural Development in China, 13681968 (Edinburgh: Edinburgh University Press, 1969), Appendix A; Mark Elvin, The Pattern of the Chinese Past (Stanford: Stanford University Press, 1973), pp. 129, 310; Colin McEvedy and Richard Jones (eds), Atlas of World Population History (Harmondsworth: Penguin Books, 1978), pp. 166-74. However, this assertion lacks support by any historical record or evidence. Although doubts on China's official statistics have been raised, (see G. W. Skinner, 'Sichuan's Population in the Nineteenth Century', Late Imperial China, 8/1 (1987), pp. 1-79), there appears to be no technical nor institutional reason for the government not to count people correctly.

2 See Kent Deng, 'Unveiling China's True Population Statistics for the Pre-Modern Era with Official Census Data', Population Review 43/2 (2004), Appendix 3. Note that it has been agreed that between the 1860s and 1920s China's annual population growth rate was still 1.4 percent; see J. K. Fairbank and Kwang-ching Liu (eds), Cambridge History of China, Late Ch'ing, 1800-1911, Part II (Cambridge: Cambridge University Press, 1980), pp. 3-4.
} 
more sustainable, decisively changing China's demographic trajectory for good (see Figure 1).

Figure 1. China's Demographic Pattern (in $10^{6}$ Persons), 1-1900 AD

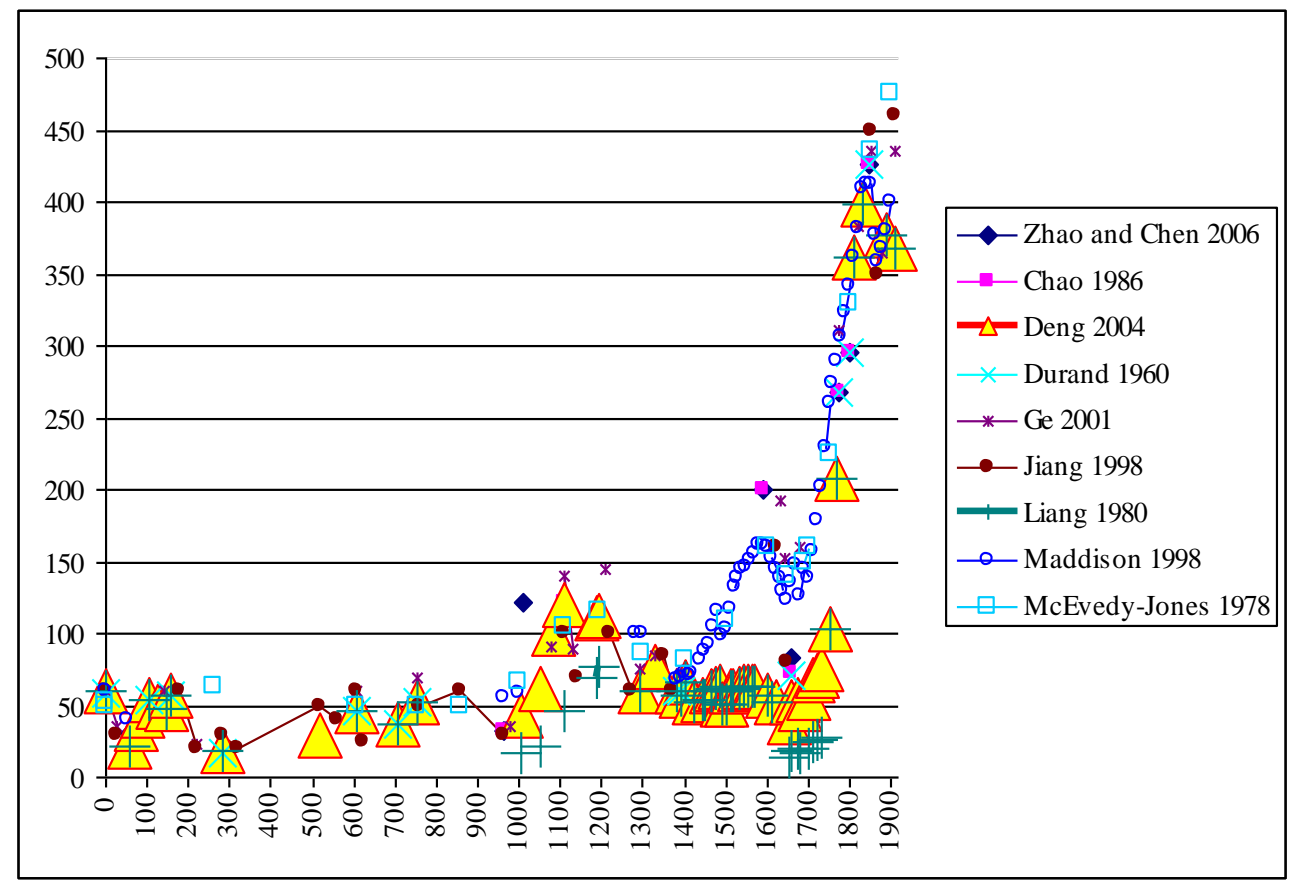

Sources: (1) Official censuses as the base-line: Liang Fangzhong, Zhongguo Lidai Hukou Tiandi Tianfu Tongji (Dynastic Data for China's Households, Cultivated Land and Land Taxation) (Shanghai: Shanghai People's Press, 1980), pp. 4-11; adjusted official population data are based on Kent Deng, 'Unveiling China's True Population Statistics for the Pre-Modern Era with Official Census Data', Population Review 43/2 (2004), pp. 1-38. (2) Estimates for comparison: J. D. Durand, 'The Population Statistics of China, A.D. 2-1953'. Population Studies, 13 (1960), pp. 209-57; Colin McEvedy and Richard Jones (eds), Atlas of World Population History (Harmondsworth: Penguin Books, 1978), pp. 166-74; Kang Chao, Man and Land in Chinese History: An Economic Analysis (Stanford: Stanford University Press, 1986), p. 41; Angus Maddison, Chinese Economic Performance in the Long Run (Paris: OECD, 1998), p. 267; Jiang Tao, Lishi Yu RenkouZhongguo Chuantong Renkou Jieguo Yanjiu (History and Demography - China's Traditional Demographic Pattern) (Beijing: People's Press, 1998), p. 84; Ge Jianxiong, Zhongguo Renkou Shi - Qing Shiqi (A Demographic History of China, Vol. 5, the Qing 
Period) (Shanghai: Fudan University Press, 2000), pp. 831-2; Zhao Gang and Chen Zhongyi, Zhongguo Tudi Zhidu Shi (A History of Land Ownership in China) (Beijing: New Star Press, 2006), p. 110.

Needless to say, the size and growth momentum of the Qing population has been subject to debate. The majority of researchers tend to agree that the official population figures for the late Qing (i.e. after 1800) were quite accurate but they challenge earlier official population figures for the late Ming and early Qing on three grounds (1) the basic unit of China's population censuses during Ming and Qing times was 'taxable persons' (ding) instead of 'natural persons' (kou) so many historians see the legitimacy to 'reconstruct' China's population of this period; (2) China's bureaucrats were unable to conduct accurate population surveys; (3) there is a ceiling for human reproduction rate/speed. Therefore, it was humanly impossible for China's population to multiply many times within two centuries during the Qing Period. The solution: to push the late Ming and early Qing official population figures higher.

It is easy to disagree on all the above three points. Firstly, one does not need to reconstruct China's population figures from 'taxable persons' to 'natural persons' in order to understand the general growth trajectory of China's population so long as a consistent census method was applied, be it 'taxable persons' or 'natural persons'. The common approach of using a fixed and constant multiplier on 'taxable persons' is unavoidably arbitrary due to the lack of national surveys of family sizes in different regions, at different times, and across different social classes. ${ }^{3}$ So, conceptually, the Ming-Qing data for taxable population are as good as one gets. In this context, although 'low' population figures were reported very consistently during entire Ming Period, 66.6 million being the highest (for 1403) and 50.3 million being the lowest (for 1490), ${ }_{4}^{4}$ it is not justifiable to 'correct' these two numbers to, for example, 72 million (with a multiplier of 1.08) and 98

\footnotetext{
${ }^{3}$ Noted here Ping-ti Ho pioneered population re-construction for the Ming population, see his Studies on the Population of China, 1368-1953 (Cambridge [Mass.]: Harvard University Press, 1959).

${ }^{4}$ Liang Fangzhong, Zhongguo Lidai Hukou Tiandi Tianfu Tongji (Dynastic Data for China's Households, Cultivated Land and Land Taxation) (Shanghai: Shanghai People's Press, 1980), p. 8.
} 
million (with a multiplier of 1.97), respectively. ${ }^{5}$ Similarly, the Ming official population figure of 56.2 million for 1600-1602 has been changed to 150 million (with a multiplier of 2.67). ${ }^{6}$ Such alteration not only changes the volume with a huge margin (close to 50 percent for 1490 and 167 percent for 1600-1602) but also switches the direction in which demographic change moved (the Ming population declined from 1403 to 1490). The real question here is whether a demographic growth should ever be so linear in reality in China's past. ${ }^{7}$

In addition, one has to ask why and how there is a 'post-1800 bias': the Qing population data after 1800 are commonly accepted more or less as they are. ${ }^{8}$ Logically, if the post-1800 data are trustworthy, so are the data produced by the same bureaucracy before 1800. Alternatively, one should consistently apply multipliers, say, 1.97 and 2.67 to the 1833 official census (i.e. 398.9 million) to make the late Qing population 785.8 or 1,065.1 million, utterly absurd as China's population reached such a level only a century later. So far, no one has either questioned or justified such ridiculous inconsistency.

Secondly, individual officials might indeed neglect their duties and falsified some local censuses. But the Qing meritocracy created a sufficient pressure on officials as a whole to perform competently. This was particularly true when there was an oversupply of imperial degree-holders after the mid-Qing who were keen on replacing underperforming bureaucrats anywhere and at any time.

Thirdly, one has to face the harsh reality of huge population losses during the MingQing transition from circa 1628 to 1661, many scholars simply ignore huge population

\footnotetext{
5 See Angus Maddison, Chinese Economic Performance in the Long Run (Paris: OECD, 1998), p. 267.

6 Cao Shuji’s Zhongguo Renkou Shi Ming Shiqi (A Demographic History of China, the Ming Period) (Shanghai: Fudan University Press, 2000), p. 3.

7 A linear growth was taken as the only pattern by Ping-ti Ho, see his Studies on the Population of China, 1368-1953 (Cambridge [Mass.]: Harvard University Press, 1959); also Zhao Wenlin and Xie Shujun, Zhongguo Renkou Shi (A Demographic History of China) (Beijing: People's Press, 1988).

8 After 1800, the Qing official population figures vary between 361 million to 398 million. So far, no one, August Maddison included, has seen these figures as 'taxable persons' so that a multiplier can be used to enlarge them. The 'readjustments' made to post-1800 official data are all lower than 10 percent, see J. D. Durand, 'The Population Statistics of China, A.D. 2-1953', Population Studies, 13 (1960), pp. 209-57; Colin McEvedy and Richard Jones, Atlas of World Population History (Harmondsworth: Penguin Books, 1978), pp. 166-74; Kang Chao, Man and Land in Chinese History: An Economic Analysis (Stanford: Stanford University Press, 1986), ch. 1.
} 
losses due to the Ming famine-civil war and the Manchu military conquest. The Ming famine-civil war alone cost about 40 million lives. ${ }^{9}$ This was followed by the widespread Manchu massacres of the Chinese across most provinces which set China's population size further back by about 7.5 million. ${ }^{10}$ It is worth noting that reliable information on such massacres comes from European sources. Martino Martini (1614-61), the Italian Jesuit to China, witnessed the Manchu systematic massacres in Fujian, Guangdong and Guangxi in his 1654 book De Bello Tartarica Historia. ${ }^{11}$ John Nieuhof (1618-72), the VOC officer who visited China at the time of the Manchu invasion and conquest also documented the Manchu massacres in his The Voyages and Travels to the East Indies $1653-1670.12$

In addition, there were subtle genocide policies to drive the ethnic Han Chinese out of their land until circa 1700. In the north, this was carried out through 'land enclosure' (quandi). The total amount of land lost by Chinese farmers was 22.9 million $m u$ in the Yellow River region alone. ${ }^{13}$ In the south, it was implemented via 'no-man zones' of 30 $l i$ wide along China's east coast. This policy evacuated farmers from 57.6 million $т и$ of land by force. ${ }^{14}$ The total loss of farmland from 'land enclosure' and 'no-man zones' was 80.5 million $m u$. If $10 \mathrm{mu}$ was the minimal size for a self-sufficient farming family, ${ }^{15}$ the homeless population were likely to be 8 million households, or 40 million individuals, although one does not know how many died in the process. The aggregate victims during the Ming-Qing transition is likely to have been 87.5 million, not at all trivial. Therefore,

\footnotetext{
9 See Cao Shuji’s Zhongguo Renkou Shi Ming Shiqi (A Demographic History of China, the Ming Period) (Shanghai: Fudan University Press, 2000), pp. 431-52.

10 Ibid., pp. 17-41.

11 Martino Martini, De Bello Tartarica Historia (Antwerp, 1654), vide: en.wikipedia.org, available on 20 February 2018.

12 John Nieuhof, Voyages \& Travels to the East Indies 1653-1670 (Reprint, Oxford: Oxford University Press, 1988).

13 Ge Jianxion, Minzu Da Qianxi (Ethnic Exodus) (Hong Kong: Zhonghua Books, 2014), p. 282.

14 See Cao Shuji's Zhongguo Renkou Shi Qing Shiqi (A Demographic History of China, the Qing Period) (Shanghai: Fudan University Press, 2000), pp. 37-41.

15 See Li Bozhong, 'Rengen Shimu Yu Mingqing Jiangnan Nongminde Jingying Guimo' (The Practice of 'Ten Mu per Farmer' and the Scale of the Traditional Peasant Economy), Zhongguo Nongshi (Agricultural History of China), 1 (1996), pp. 1-14.
} 
the low baseline for the early Qing population can well be justified. The low baseline also explains the adoption of a benevolent population policy by Emperor Kang Xi in 1712 known as 'no more tax burden to let population thrive'. 16

Now, for the sake of argument, a net annual growth rate of mere 0.7 percent (gross birth rate - infant mortality rate - death rate) will quadruple a population in 200 years; and a net annual growth rate of one percent will at least sextuple a population. As far as one can tell, 0.7-1.0 percent net population growth was highly achievable during the Qing. ${ }^{17}$

For all these reasons, the current study uses China's official census only with the belief that the Qing official data deserves the benefit of the doubt.

Regarding the quality of studies of the Qing population, many scholars - mainly historical demographers and archivists - have adopted a strictly descriptive mode when dealing with such significant fluctuations of the Qing population, as if there were no particular need for an explanation. ${ }^{18}$ Similarly, some have taken the Qing population size for granted in so far as to use it as a proxy for the size and health of the economy. ${ }^{19}$ Yet, such an approach leads to circular argumentation: a large population was fed by a large economy, and a large economy supported a large population. So what?

Some recent works have tried to turn the problem on its head by looking for evidence that would indicate there was a much smaller population increase than previously suggested. A study, for example, has argued that the change in the Qing family size was

16 Zhao Erxun, Qingshi Gao (Draft of the History of the Qing Dynasty) (1927), vol. 9 'Shizong Benji' (Biography of Emperor Shizong), in Twenty-Five Official Histories, vol. 11, p. 8853.

17 See James Lee, Cameron Campbell, and Guofu Tan, 'Infanticide and Family Planning in Late Imperial China', in Thomas Rawski and Lillian Li, eds., Chinese History in Economic Perspective (Berkeley: University of California Press, 1992), pp. 145-76; James Lee and Cameron Campbell, Fate and Fortune in Rural China (Cambridge: Cambridge University Press, 1997), pp. 55-7, 70.

18 J. D. Durand, 'The Population Statistics of China, A.D. 2-1953'. Population Studies, 13 (1960), pp. 209-57; McEvedy and Jones, Atlas of World Population History, pp. 166-74; Liang Fangzhong, Zhongguo Lidai Hukou Tiandi Tianfu Tongji (Dynastic Data for China's Households, Cultivated Land and Land Taxation) (Shanghai: Shanghai People's Press, 1980), pp. 4-11; Jiang Tao, Lishi Yu Renkou - Zhongguo Chuantong Renkou Jieguo Yanjiu (History and Demography - China's Traditional Demographic Pattern) (Beijing: People's Press, 1998), p. 84; Ge Jianxiong, Zhongguo Renkou Shi - Qing Shiqi (A Demographic History of China, Vol. 5, the Qing Period) (Shanghai: Fudan University Press, 2000), pp. 831-2.

19 E.g. Maddison, Chinese Economic Performance, p. 267; Zhao Gang and Chen Zhongyi, Zhongguo Tudi Zhidu Shi (A History of Land Ownership in China) (Beijing: New Star Press, 2006), p. 110. 
marginal. ${ }^{20}$ Moreover, it has been proposed that preventive checks, both ex ante (herbal contraception) and ex post (infanticide), were extensively practiced at the household level, meaning that the Qing population may have been consciously controlled. ${ }^{21}$ On its own, however, the preventative argument is incompatible with the weight of evidence indicating that China's population quadrupled over the period. Such preventative checks, therefore, would had to either occurred very late in the period, and/or on very small scale, such that their effect was not significant enough to impact the overall population growth dynamics.

Meanwhile, why and how the remarkable Qing population growth occurred has remained open to debate. Implicitly or explicitly, a Malthusian paradigm is often used when the doubling of China's territory under the Qing is considered. ${ }^{22}$ Intuitively, territorial expansion could lead to more resource endowments and then to more population growth. However, China's territorial increases did not automatically warrant a larger population. By the Tang Period (618-907), China's population had remained below 60 million, regardless of two major increases in the empire's territory during the Western Han (206 BC - 25 AD) and the Tang. During the Northern Song (960-1127), China shrank back to the size under the Qin (221 BC - 207 BC), but its population exceeded 100 million, the largest hitherto in China's history. Under the Mongol colonisation, China's territory expanded to its historical pinnacle, but China's population stagnated at the 50-60 million level. Under the Qing, China's territory bounced back to a size between that of the Tang (618-907 AD) and Yuan (1271-1368) (see Figure 2). So, more territory can be viewed at best as a necessary but not sufficient condition for China's population increase.

\footnotetext{
20 Lee and Wang, One Quarter of Humanity, pp. 34-5, 38.

21 Feng Wang, James Lee and Cameron Campbell, 'Marital Fertility Control among the Qing Nobility', Population Studies 49/3 (1995), pp. 383-400; Li Bozhong, 'Qingdai Qianzhongqi Jiangnan Renkoude Disu Zengzhang Jiqi Yuanyin' ('The Low Population Growth in the Yangtze Delta and its Reason during Early and Mid-Qing Times'), Qingshi Yanjiu (Study of Qing History), 2 (1996), pp. 10-19; Li Bozhong, Duoshijiao Kan Jiangnan Jingjishi, 12501850 (Multiple Dimensional View on Economic History of the Jiangnan Region, 1250-1850) (Beijing: Sanlian Books, 2003), pp. 137-212.

22 E.g. J. K. Fairbank and Merle Goldman, China: A New History (Harvard University Press, 2005), pp. 143-62; J. D. Spence, The Search for Modern China, third edition (New York: Norton, 2012), chs 2, 4 and 5; G. D. Rawnsley and M. T. Rawnsley (eds.), Political Communications in Greater China (London: RoutledgeCurzon, 2003), pp. 10-38.
} 
Figure 2. Fluctuations in China's Territory,*221 BC - 1911 AD

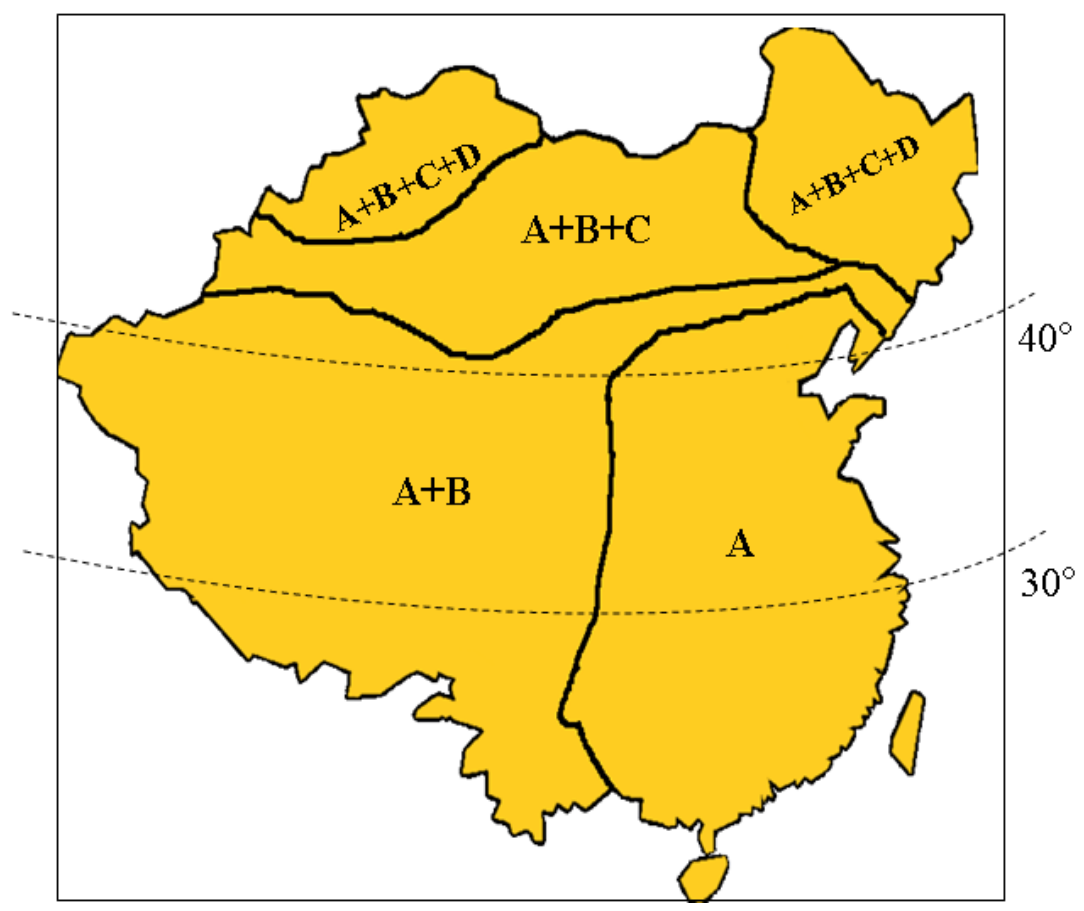

Source: Based on Tan Qixiang, Jianming Zhongguo Lishi Dituji (Concise Maps of Chinese History) (Beijing: China's Map Press, 1991), pp. 15-18, 39-40, 57-8, 67-8.

Note: * Here, the Qing (1644-1911) boundaries are used as a template. A $=$ the Qin territory (c. $207 \mathrm{BC}$ ) and roughly the Northern Song territory (960-1127); A + B = the Western Han territory (c. $24 \mathrm{AD}$ ); A + B + C = the Tang territory (c. 907); A + B + C + $\mathrm{D}=$ the Qing territory (c. 1911) and roughly the Yuan territory (1279-1368).

A fuller understanding is obtained by recognising that institutions played a vital part in determining the space for population growth under resource constraints. For instance, under the Mongol colonisation of China, genocide against the Han Chinese took place under a mindset described as, 'the Chinese are useless to our cause, and should be killed off so that their land can be converted to grazing land'. ${ }^{23}$ Among those Han Chinese who survived, millions were enslaved (quding); horses belonging to the Chinese were confiscated; vast agrarian areas were enclosed as grazing land; a second crop after the

23 Song Lian, Yuan Shi (History of the Yuan Dynasty) (1371), vol. 153: no. 146 'Yeluchucai Zhuan' ('Biography of Yeluchucai'), in Er-shi-wu Shi (Twenty-Five Official Histories) (Shanghai: Shanghai Classics Press, 1986), vol. 9, p. 7635; see also A. F. Wright and Denis Twitchett (eds), Confucian Personalities (Stanford: Stanford University Press, 1962), pp. 19-20, 189-216. 
summer harvest was forbidden in order to make space for Mongol horses; taxation burden multiplied. ${ }^{24}$ All such policies effectively counteracted any possible resource windfall that would allow for more population growth.

In sharp contrast to the Mongol policies, the Qing territorial expansion was coupled with the government physiocratic commitment. Private land ownership was granted to the Han Chinese. Government schemes deliberately proliferated owner-tiller farms into new frontiers including Manchuria and South Mongolia. Efforts were also made to open up the north-western region of Gansu and Xinjiang and the south-western region of Sichuan, Guizhou and Yunnan, all for farming. 25 These schemes left only Tibet and neighbouring Qinghai untouched.

The supply of farmland under the Qing became without doubt more elastic. The additional farmland supply in Manchuria and South Mongolia alone was equivalent to about one-sixth of China's total. China's farmland more than doubled in the first 100 years of the Qing rule (see Figure 3). Thus, we consider the first factor in relation to the Qing population growth to be supply of farmland. The current research examines the impact of such a supply on the Qing population. ${ }^{26}$

Figure 3. Supply of Farmland versus Population Growth, 1650-1900

\footnotetext{
24 Wang Qi, Xu Wenxian Tongkao (Imperially Commissioned Continuation of the Comprehensive Study of Literature) (publisher unknown, 1586), vol. 1; Perkins, Agricultural Development in China, pp. 23-4, 197-9; Zheng Xuemeng, Jiang Zhaocheng and Zhang Wenqi, Jianming Zhongguo Jingji Tongshi (A Brief Panorama of Chinese Economic History) (Harbin: Heilongjiang People's Press, 1984), pp. 242-4, 254-5.

25 By the 1820s, the new farmland in the Balikun and Yili regions of Xinjiang (also known as 'Chinese Turkistan') alone totalled 908,500 mи or 121,735 hectares; see Chen Hua, Qingdai Quyu Shehui Jingji Yanjiu (Regional SocioEconomic Conditions during the Qing Period) (Beijing: People's University Press, 1996), p. 265; J. K. Leonard and J. R. Watt (eds.), To Achieve Security and Wealth (Ithaca: Cornell University East Asia Program, 1992), pp. 21-46.

26 The elastic supply of farmland contradicts the well-circulated notion — known as the 'man-land ratio argument' — that arable land under the Qing was fixed and thus its workforce had to farm more intensively to keep up with an increasing population; see Kang Chao, Man and Land in Chinese History: An Economic Analysis (Stanford: Stanford University Press, 1986).
} 


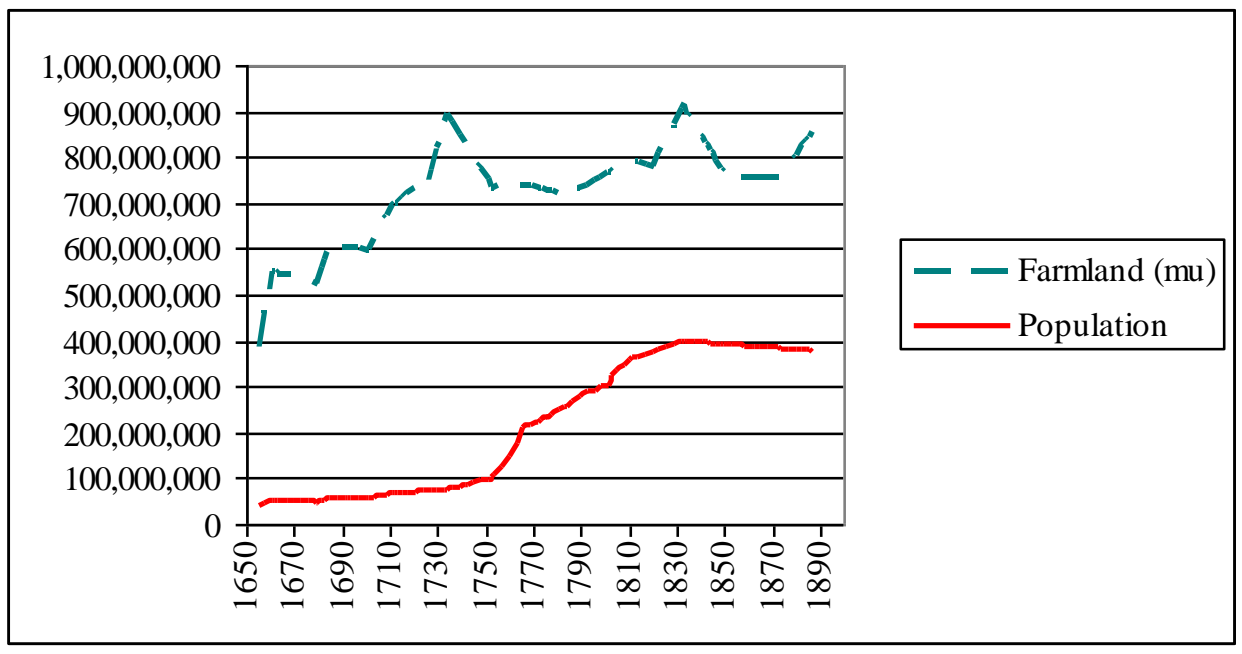

Sources: Farmland is based on Liang, Dynastic Data, pp. 10, 380, 384, 396, 400, 401. Population is based on Deng, 'Unveiling China's True Population Statistics'.

Note: Farmland in $m u$. One Qing $m u=614.4 \mathrm{~m}^{2}$. Population in persons.

Concomitant with the impact of farmland supply providing support for the Qing population growth was labour mobility. During the Qing, the scale of internal migration was greater than that of the previous Ming Period (see Figure 4). The impetus for such increased migration level was the Qing policy of 'farming by invitation' (quannong), which actively encouraged farmers to occupy newly available farmland, including old core farming regions such as Shanxi, Zhejiang, Hunan, Fujian and Guangdong.

Figure 4. Internal Migration Index (1369 = 100), 1369-1900

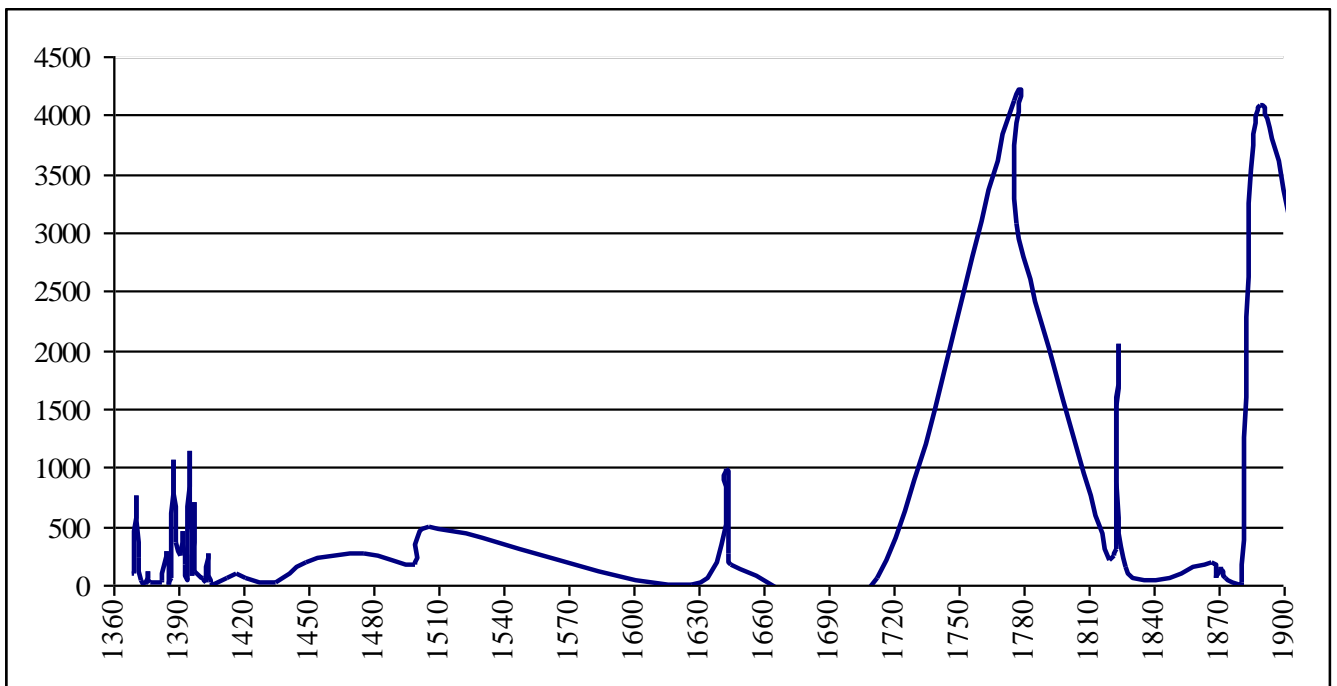


Source: Ge Jianxiong (ed.), Zhongguo Yimin Shi (A History of Migration in China) (Fuzhou: Fujian People's Press, 1997), vol. 1, pp. 342-40.

Note: Ordinate - persons. Abscissa - Calendar years.

The concern behind the Qing migration policy was an explicit economy-wide resource re-allocation policy called 'filling regions with land abundance with population from regions of high population density' ('yi zhai bu kuan'). ${ }^{27}$ Often, the Qing state provided migrants with free passage, working capital (seed and tools) and tax holidays for a number of years. Overall, the policy proved effective (see Table 1).

Table 1. Internal Economic Migration during the Qing Period

$\begin{array}{ll}\text { Donor Region } & \text { Recipient Region } \\ \text { Shanxi } & \text { Sichuan } \\ \text { Hunan } & \text { Guangdong, Fujian } \\ \text { Anhui, Hubei } & \text { Shanxi } \\ \text { Henan, Jiangxi } & \text { Shanxi } \\ \text { Hunan, Guangdong } & \text { Sichuan } \\ \text { Jiangxi } & \text { Fujian } \\ \text { Fujian, Guangdong } & \text { Hunan } \\ \text { Fujian } & \text { Zhejiang, Taiwan } \\ \text { Shandong } & \text { Manchuria } \\ \text { Shanxi } & \text { Mongolia }\end{array}$

Source: Ge Jianxiong (ed.), Zhongguo Yimin Shi (A History of Migration in China) (Fuzhou: Fujian People's Press, 1997), vol. 1, pp. 169-402.

27 Anon., Qing Gaozong Shilu (Veritable Records of Emperor Gaozong of the Qing Dynasty) (1799. Reprint. Taipei: Hualian Press, 1964), vol. 311, Entry 'Shisannian Sanyue’. 
Note: The actual numbers of migrants are difficult to assess. Often, only vague amounts are mentioned in reference to a migration scheme, such as, 'several tens of thousands of persons or households', or ' 60 to 70 percent of the locals migrated'.

Large numbers of migrants from the old core regions (such as Shandong, Shanxi, Shaanxi, Hebei, and Henan) resettled elsewhere for a better life. ${ }^{28}$ By 1668 , the frontier region of Manchuria had absorbed 14 million immigrants from China proper. ${ }^{29}$ In the nineteenth century, the annual immigrants to that region were 600,000 . By the very end of the Qing (at 1907), the government immigration quota for Heilongjiang, the northern tip of Manchuria, was two million per year. ${ }^{30}$ Large-scale immigration also took place in Mongolia. In 1712, the number of immigrants from Shandong counted for over 100,000. ${ }^{31}$ As a result, modern-day Manchuria, Mongolia and Sichuan are lineage enclaves of clans from Shandong, Hebei, Hubei and Hunan. ${ }^{32}$

Likewise in Sichuan near the upper reaches of the Yangtze River, a surge of immigration began in 1713 under Emperor Kangxi's edict of 'filling up Sichuan with the

28 For the eighteenth century, see Pierre-Etienne Will, Bureaucracy and Famine in Eighteenth-Century China (Stanford: Stanford University Press, 1990), pt. 2.

29 Anon., Veritable Records of Emperor Gaozong of the Qing Dynasty, vol. 311, Entry 'Shisannian Sanyue' (The Third Month of the Thirteenth Year under the Gaozong Reign).

30 Tian and Chen, Brief History of Migration, pp. 110-12.

31 The Qing state eventually imposed a ban on permanent immigration to Manchuria (1668-1860) and Mongolia (1740-1897). But there was little control over seasonal migrants to both regions. Moreover, by the time when the restriction was introduced in 1740-2, a large number of immigrants had already settled in; see Zhao Erxun, Qingshi Gao (Draft of the History of the Qing Dynasty) (1927), vol. 120 'Shihuo Zhi' (Economy), in Twenty-Five Official Histories, vol. 11, pp. 9252-9.

32 Yuan Yida and Zhang Cheng, Zhongguo Xingshi Qunti Yichuan He Renkou Fenbu (Chinese Surnames, Group Genetics and Demographic Distribution) (Shanghai: East China Normal University Press, 2002), pp. 6-57. 
population from Hubei' (huguang tian sichuan). ${ }^{33}$ In 1743-8 alone, a quarter of a million migrants re-settled there. ${ }^{34}$ Minor waves of migration also occurred elsewhere. ${ }^{35}$

Such vigorous economic-driven migration and farming resettlement significantly altered China's resource allocation regarding labour, capital, technology and land. However, the actual impact of this economic migration on Qing population growth has thus far remained unclear. This study regards internal migration as inherently related to the increase in farmland. In other words, new gains in farmland became an effective factor in the economy only because new immigrants settled and farmed the new land. We thus consider internal migration attached to the factor of farmland.

The second factor we find central to explaining Qing population dynamics is food production. Some scholars see the Qing population growth as subject to technological determinism. Mark Elvin's heuristic 'High-Level Equilibrium Trap' hypothesises a mutually-reinforcing mechanism between labour-intensive agriculture and population density until the Qing economy reached equilibrium. Under his argument, China's technology was fixed indefinitely and only imported new technology could unlock China's equilibrium. ${ }^{36}$ Elvin's approach has been modified by Francesca Bray who, inspired by Ester Boserup, ${ }^{37}$ argued specifically that rice-farming was the determinant for China's (as well as the whole of Monsoon Asia's) demographic pattern. She presented a notion that rice production suffers little diminishing returns and hence eliminates the ceiling for population growth. ${ }^{38}$ In other words, under rice farming, population growth becomes unlimited. Evidence suggests, however, that the average wheat yield level

33 Tian Fang and Chen Yijun, Zhongguo Yimin Shilue (Brief History of Migration in China) (Beijing: Knowledge Press, 1986), pp. 113-14; Chen, Regional Socio-Economic Conditions, ch. 8; Jiang Tao, Renkou Yu Lishi, Zhongguo Chuantong Renkou Jiego Yanjiu (Population and History, A Study of Chinese Traditional Demographic Structure) (Beijing: People's Press, 1998), p. 96.

34 Anon., Veritable Records of Emperor Gaozong of the Qing Dynasty, vol. 311, Entry 'Shisannian Sanyue' (The Third Month of the Thirteenth Year under the Gaozong Reign).

35 James Lee, 'Population Growth in Southwest China, 1250-1850', The Journal of Asian Studies, 41/4 (1982), pp. 711-46.

36 Elvin, The Pattern of the Chinese Past, ch. 9.

37 Ester Boserup, The Conditions of Agricultural Growth: The Economies of Agrarian Change under Population Pressure (London: Allen and Unwin, 1965).

38 Bray, The Rice Economies. 
remained largely unchanged while the average rice yield level increased but modestly (see Figure 5). This suggests that the Qing crop yield levels remained very stable over time. 39

Figure 5. Crop Yield Levels, 1640-1910

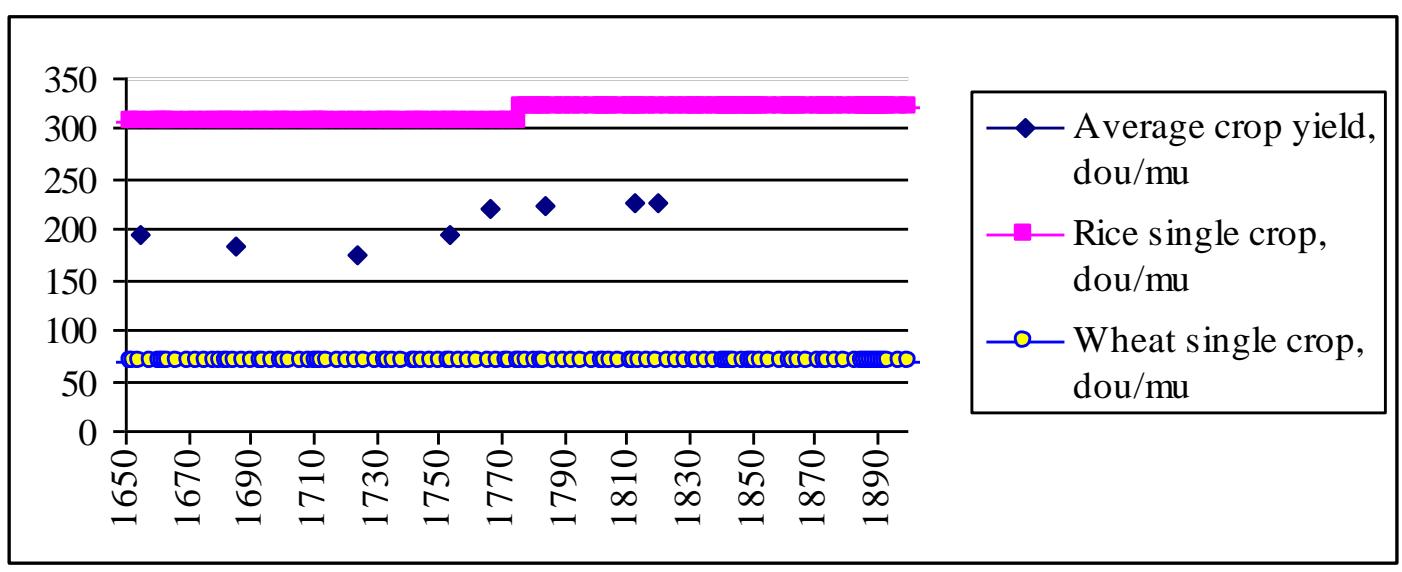

Source: Shi Zhihong, 'Shijiu Shiji Shangbanqide Zhongguo Liangshi Muchanliang Ji Zongchanliang Zai Guji' (Re-Estimation of Yields per $M u$ and the Aggregate Food Output in Early Nineteenth Century China), Zhongguo Jingjishi Yanjiu (Research into Chinese Economic History) 3 (2012), pp. 52-66.

Note: Rice and wheat crops only. (1) Average rice yields from 12 southern provinces (Anhui, Jiangsu, Zhejiang, Hubei, Hunan, Jiangxi, Fujian, Guangdong, Guangxi, Sichuan, Guizhou, Yunnan), (2) average wheat yields from 8 northern provinces (Zhili, Shandong, Shanxi, Henan, Shaanxi, Gansu, Manchuria, Xinjiang), counting one crop only.

Similarly, Kang Chao has argued that, with China's arable land being fixed, the Qing peasantry had to farm more, and more intensively, to increase food provision. ${ }^{40}$ However, the reality was that in Shandong, Jiangnan, Fujian and Guangdong - places where food shortage perpetuated during the Qing - local farmers did not necessarily farm more

\footnotetext{
39 According to Wu Hui, there was mere a 1.7 percent increase in China's crop yield level from the Ming to the Qing; see Wu Hui, Zhongguo Jingjishi Rugan Wentide Jiliang Yanjiu (Quantitative Studies of Chinese Economic History) (Fuzhou: Fujian People's Press, 2009), p. 147.

40 Chao, Man and Land in Chinese History, ch. 1.
} 
intensively for staple food. ${ }^{41}$ Instead, they often grew more cash crops, especially cotton, tea and, later tobacco, in exchange for rice imported from food-surplus regions. ${ }^{42}$ This was rural 'involution' in full swing. ${ }^{43}$ There were as many as ten shipping routes running from rice-surplus provinces to cash crop producing provinces, transporting as much as 36-57 million piculs (shi) of rice per annum. ${ }^{44}$ Since one picul contained 75 kilograms, this makes the total shipment 2.7-4.3 million tonnes. Given that it takes 180 kilograms of cereal to maintain an adult at the subsistence level, approximately 15-24 million adults were able to live entirely on imported rice in the four food-deficit provinces.

Other scholars see new crop species from outside the empire as a new driver for the Qing population growth. These were the 'New World crops' - maize (Zea mays), white potatoes (Solanum tuberosum) and sweet potatoes (Ipomoea batatas). ${ }^{45}$ Anecdotal

41 Contemporary scholars such as Li Bozhong and Pomeranz mention little about the New World crops in the MingQing Jiangnan region. See Li Bozhong, Duoshijiao Kan Jiangnan Jingjishi, 1250-1850 (Multiple Dimensional View on Economic History of the Jiangnan Region, 1250-1850) (Beijing: Sanlian Books, 2003); Kenneth Pomeranz, The Great Divergence, Europe, China and the Making of the Modern World Economy (Princeton: Princeton University Press, 2000).

42 Chen Hua, Qingdai Quyu Shehui Jingji Yanjiu (Regional Socio-Economic Conditions during the Qing Period) (Beijing: People's University Press, 1996), pp. 106-7; K. L. So, Prosperity, Region, and Institutions in Maritime China, the Fukien Pattern, 946-1368 (Cambridge [MA]: Harvard University Asia Center, 2000), pp. 95-6.

43 Philip Huang, The Peasant Economy and Social Change in North China (Stanford: Stanford University Press, 1985); Chen Chunsheng and Liu Zhiwei, 'Qingdai Jingji Yunzuode Liangge Tedian' (Two Characteristics of Qing Economic Operation), Zhongguo Jingjishi Yanjiu (Research into Chinese Economic History), 3 (1990), pp. 84-9.

44 Wu Chengming, Zhongguode Xiandaihua: Shichang Yu Shehui (China's Modernisation: the Market and Society) (Beijing: Sanlian Books, 2001), pp. 152-7; Zhang Haiying, Mingqing Jiangnan Shangpin Liutong Yu Shichang Tixi (Commodity Flows and Market Structure in the Jiangnan Region during the Ming-Qing Period) (Shanghai: East China Normal University Press, 2001), pp. 198-203; Wu, Quantitative Studies of Chinese Economic History, p. 376.

45 These crops were introduced in the following sequence: Sweet potato vines (fanshu, Ipomoea batatas) were smuggled to China from Luzon in 1593. Maize (yumi, Zea mays) was first mentioned in Li Shizhen's Compendium of Materia Medica (Bencao Gangmu) written in 1578 (Reprint. Beijing: People's Press, 1977), vol. 23; and then in Xu Guangqi's Nongzheng Quanshu (Complete Treatise on Agricultural Administration of 1628 (Reprint. Shanghai: Shanghai Classics Press, 1979), p. 629. The white potato (malingshu, Solanum tuberosum) was first introduced to Taiwan around 1650. See Guo Wentao, Zhongguo Nongyie Keji Fazhan Shilue (A Brief History of Development of Agricultural Science and Technology in China) (Beijing: Chinese Science and Technology Press, 1988), pp. 383-4. Yet until the 1630s, their spread was very limited. According to Song Yingxing's Exploitation of the Works of Nature (Tiangong Kaiwu) of 1637, seventy percent of the Chinese lived on rice and thirty percent on wheat, barley, sorghum and millet. The New World crops were excluded; see Song Yingxing, Tiangong Kaiwu (Exploitation of the Works of 
evidence suggests that in the early seventeenth century, sweet potatoes were able to yield ten times (gross weight) that of rice; 46 similarly, maize allegedly increased the land yield by 30 percent. ${ }^{47} \mathrm{~A}$ common assumption has thus been made that there was a close link between these crops and the fast growth in China's population. ${ }^{48}$ In this study, we clarify the role of the New World crops in regard to the Qing population growth. The spread of new crops is our third factor.

A complicating issue, however, is that not until the first comprehensive survey of China's agrarian economy in the 1920s was the geographic spread of New World crops ever systematically mapped. 49 Therefore, due to data availability, we use maize as a representative for these crops. Official records for the spread of sweet potatoes are limited to the provincial level (18 provinces governed by the Qing Court). ${ }^{50}$ Official records for maize are much better: at the county level (over 1,300 counties). ${ }^{51}$ However, there is no record on the actual sown area for sweet potato or maize. Thus, we use the

Nature) (1637. Reprint. Guangzhou: Guangdong People's Press, 1976), p. 11. These crops became better known during the Qing Period.

46 Shi Shenghan, Nongzheng Quanshu Jiaozhu (Annotated Edition of the 'Complete Treatise on Agricultural Administration') (Shanghai: Shanghai Classics Publisher, 1979), p. 692.

47 See J. K. Fairbank and Kwang-ching Liu (eds), Cambridge History of China, Late Ch'ing, 1800-1911, Part II (Cambridge: Cambridge University Press, 1980), p. 11. Also see R. H. Myers, The Chinese Peasant Economy: Agricultural Development in Hopei and Shangtung, 1890-1949 (Cambridge [MA]: Harvard University Press, 1970), Appendix.

48 E.g. Mark Elvin, The Pattern of the Chinese Past (Stanford: Stanford University Press, 1973), p. 298; F. W. Mote, Imperial China, 900-1800 (Cambridge [MA]: Harvard University Press, 1999), p. 750; L. E. Stover and T. K. Stover, China: an Anthropological Perspective (Pacific Palisades [CA]: Goodyear Publishing Co., 1976), p. 115. See also, Lee James, 'Population Growth in Southwest China, 1250-1850' The Journal of Asian Studies, 41/4 (1982), pp. 711-46; L. E. Stover and T. K. Stover, China: an Anthropological Perspective (Pacific Palisades [CA]: Goodyear Publishing Co., 1976), p. 115. See also, Lee James, 'Population Growth in Southwest China, 1250-1850' The Journal of Asian Studies, 41/4 (1982), pp. 711-46.

49 J. L. Buck, Land Utilization in China: Atlas (London: Oxford University Press, 1937).

50 Jia, Ruixue, 'Weather Shocks, Sweet Potatoes and Peasant Revolts in Historical China', The Economic Journal, 124/575 (2014), pp. 92-118; cf. Chen Shuping, 'Yumi He Fanshu Zai Zhongguo Chuanbo Qingkuang Yanjiu' (Studies of the Spread of Maize and Sweet Potatoes in China), Zhongguo Shehui Kexue (Social Sciences in China), 3 (1980), pp. 188-204.

51 Xian Jinshan, 'Cong Fangzhi Jizai Kan Yumi Zai Woguode Yinjin He Chuanbo' (Adoption and Spread of Maize Seen from Local Gazetteers), Gujin Nongye (Agriculture, Past and Present), 1 (1988), pp. 99-111. 
geographic spread of maize-farming as a proxy for the new farming technology of the time (see Figure 6).

Figure 6. Spread of Maize-farming (\% of All Counties), 1650-1910

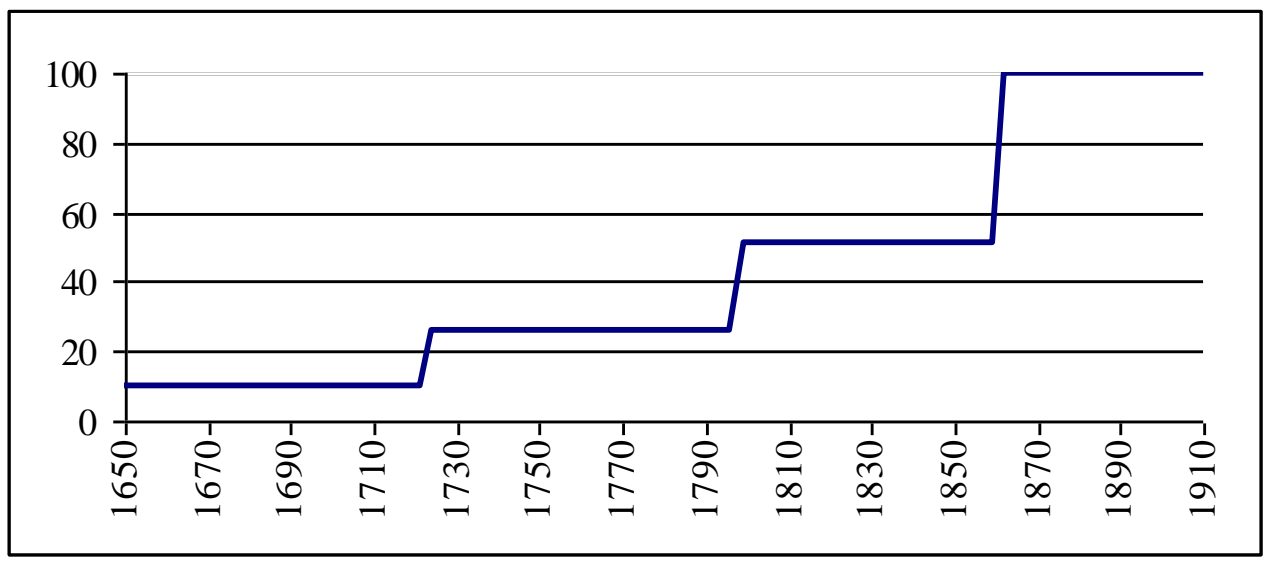

Source: Xian Jinshan, 'Cong Fangzhi Jizai Kan Yumi Zai Woguode Yinjin He Chuanbo’ (Adoption and Spread of Maize Seen from Local Gazetteers), Gujin Nongye (Agriculture, Past and Present), 1 (1988), pp. 99-111.

The fourth factor we consider is the tax burden imposed on the citizenry. We are fully aware rent-seeking by the gentry class in the form of local dues/surcharges on the village level and often against the law. However, one has to distinguish gentry's rent-seeking from legal revenue extraction by the state. After all, the number of officials on the Qing government payroll was a trivial fraction of the Imperial Degree-holders in society. ${ }^{52}$ One has to separate salaried officials from non-salaried gentry members. Otherwise, the state behaviour will no longer be identifiable. In the beginning of the Qing rule, the heavy taxes of the previous Ming Period were abandoned, a policy known as 'abolishment of

\footnotetext{
52 To understand where the gentry ended and the bureaucracy began during the Qing, see Chung-li Chang, The Chinese Gentry: Studies on Their Role in Nineteenth-Century Chinese Society (Seattle: University of Washington Press, 1955), pp. 83-92; J. K. Fairbank, Chinese Thought and Institutions (Chicago: Chicago University Press, 1957), pp. 25168; Ping-ti Ho, The Ladder of Success in Imperial China (New York: Columbia University Press, 1962), p. 262; Deng Ciyu, Zhongguo Kaoshi Zhidu Shi (History of the Chinese Imperial Examination System) (Taipei: Xuesheng Books, 1967), pp. 163-4; and Wang Dezhao, Qingdai Keju Zhidu Yanjiu (Civil Examinations during the Qing Period) (Hong Kong: The Chinese Univerisyt Press, 1982), pp. 65-6.
} 
the Ming practice' (fei mingfa). ${ }^{53}$ Until 1840 when fiscal crises occurred, the Qing bureaucracy maintained strong distaste for tax increases. ${ }^{54}$ In 1712, the total revenue of the Land-Poll Combined Tax (diding) was frozen for good to allow surpluses to be retained by ordinary households. ${ }^{55}$ As a result, the highest annual tax revenue collected in grain under the Qing (as of 1820) was 29 percent of its Ming counterpart (as of 1502). The Qing tax burden per unit of land (as of 1661) was 17 percent of the peak of the Ming (as of 1542). ${ }^{56}$ The Qing tax burden per capita (as of 1766) was 8 percent of the Ming (as of 1381). ${ }^{57}$ Conceptually, a significantly declining tax burden benefited population growth (see Figure 7).

Figure 7. Tax Burden Indices $(1660=100), 1660-1900$

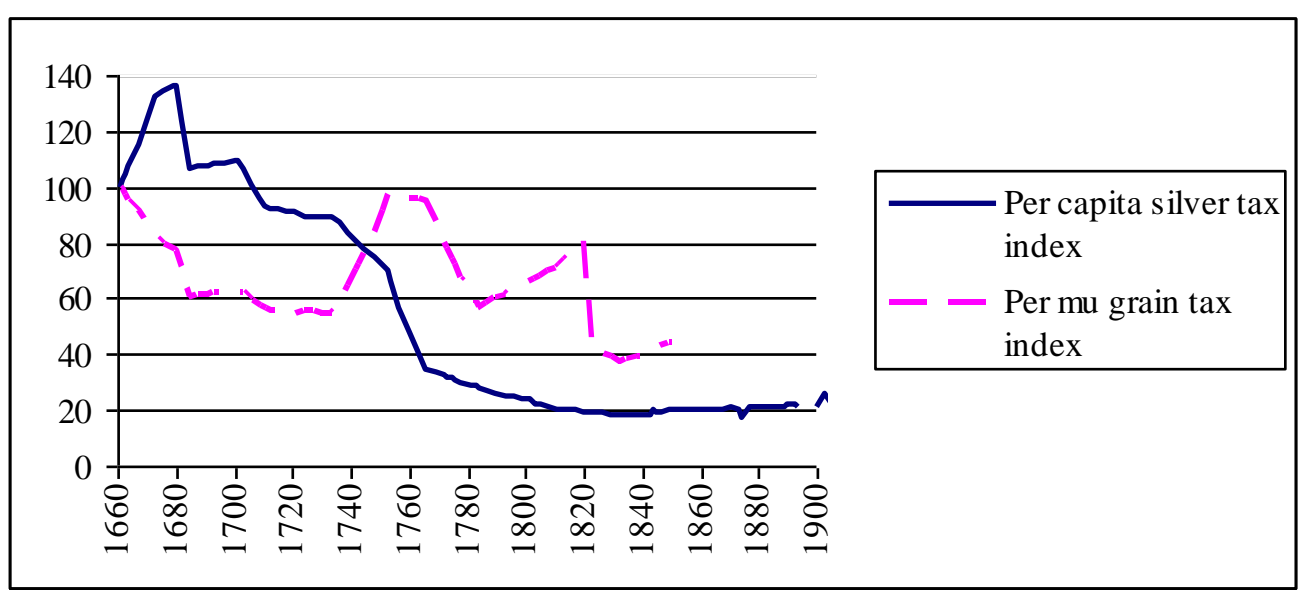

Sources: Population is based on Deng, 'Unveiling China's True Population Statistics'. Farmland is based on Liang, Dynastic Data, pp. 396, 400, 401. Taxes are based on Liang, Dynastic Data, pp. 10, 380, 384; Xiang Huaicheng, Zhongguo Caizheng Tongshi (A

53 Zhao, Draft of the History of the Qing Dynasty, vol. 14 'Shizuji Yuannian' (Biography of Emperor Shizu, the First Year of His Reign).

54 W. J. Peterson (ed.), The Cambridge History of China (Cambridge: Cambridge University Press, 2002), vol. 9. pp. 604-5.

55 Deng, China's Political Economy, pp. 16-18.

56 Gang Deng, The Premodern Chinese Economy - Structural Equilibrium and Capitalist Sterility (London and New York: Routledge, 1999), p. 124.

57 Liang, Dynastic Data, p. 428. 
General History of Government Finance in China) (Beijing: China's Finance Press, 2006), vol. 8, pp. 78, 222.

Exogenous shocks can also affect the standing population. During the first 100 years of the Qing rule, while the number of natural disasters increased, the total number of all disasters (natural and man-made) declined (see Figure 8).

Figure 8. Qing Disaster Index $(1646=100), 1646-1910$

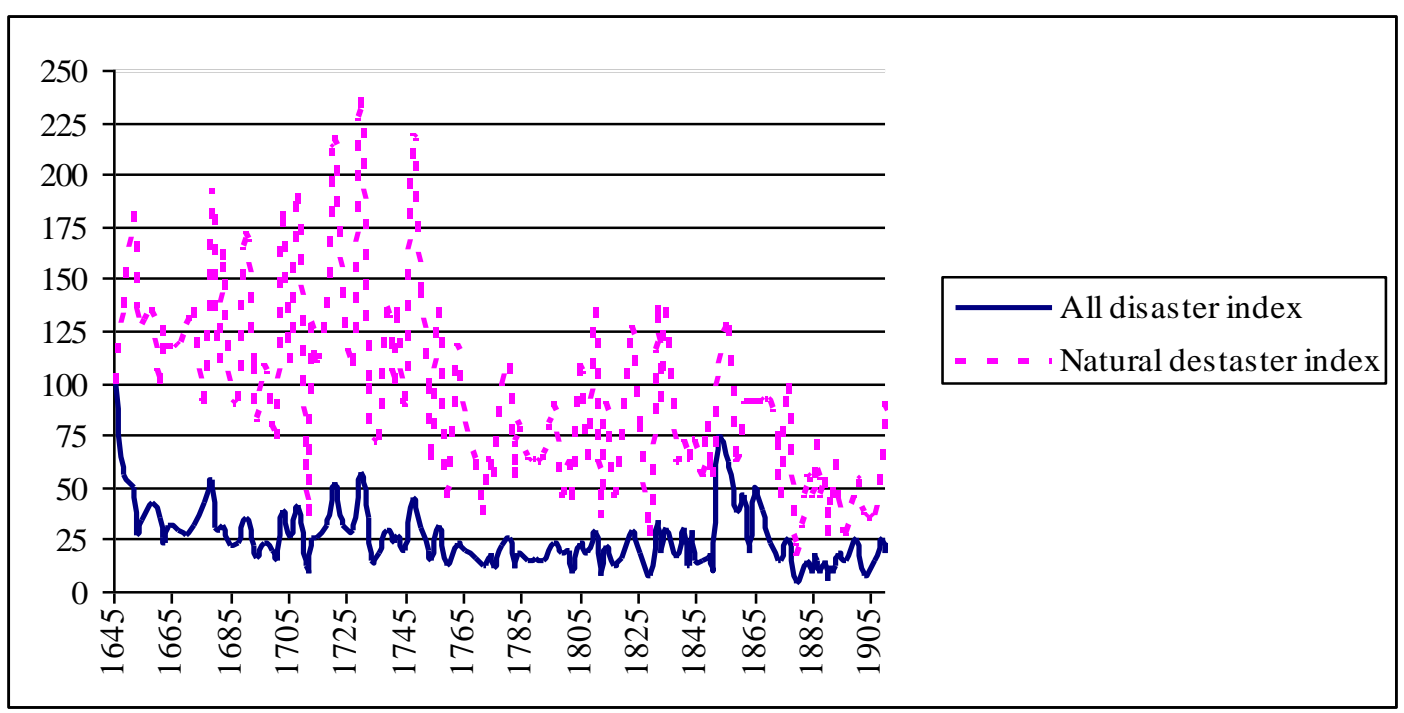

Source: Chen Gaoyong, Zhongguo Lidai Tianzai Renhuo Biao (Chronological Tables of Chinese Natural and Man-made Disasters) (Shanghai: Jinan University Press, 1937).

We consider government spending on disaster relief as the fifth factor. Ever since the early Qing, the state provided the population with a safety net against famine (see Figure 
9). ${ }^{58}$ Relief aid during a bad year sometimes exceeded the state annual tax revenue several times over. 59

Figure 9. Qing Disaster Relief Recipient Index (1646 = 100), 1646-1910

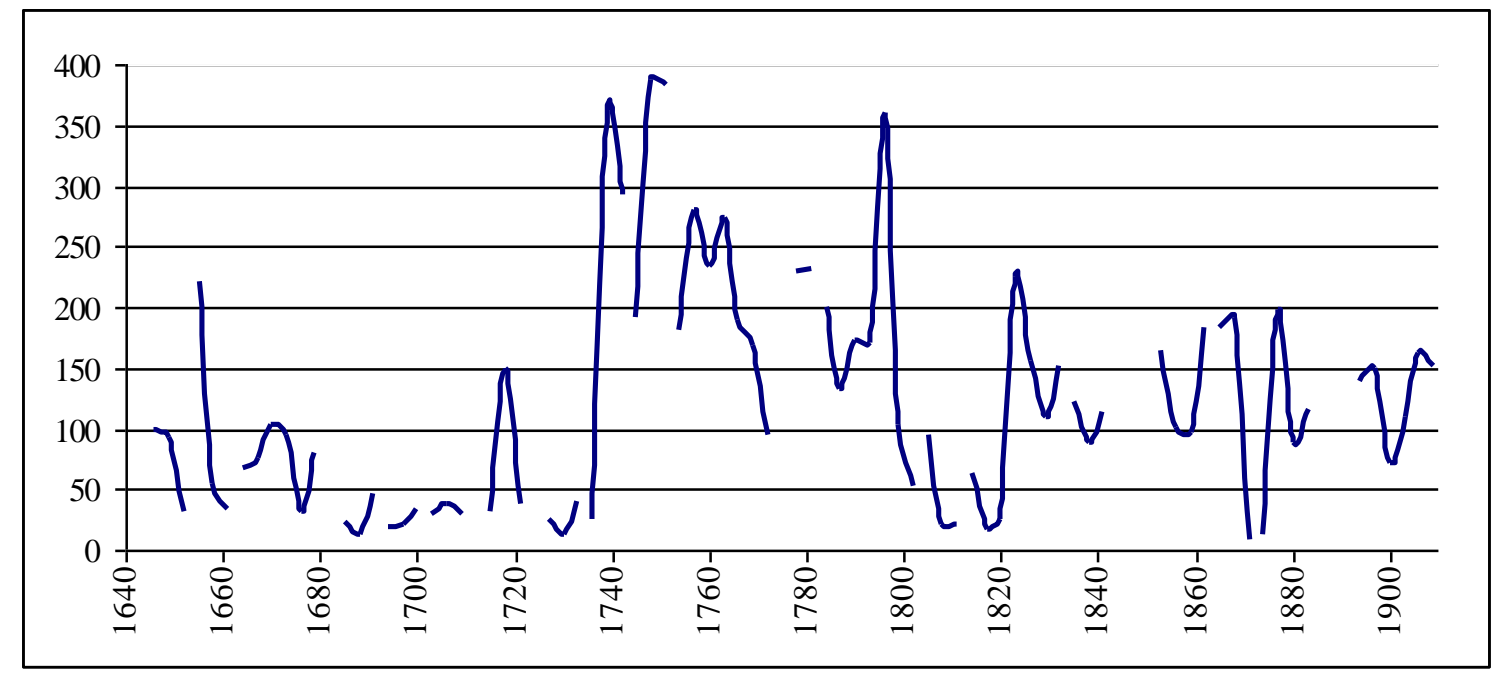

Source: Zhao Erxun, Qingshi Gao (Draft of the History of the Qing Dynasty) (1927), vols 4-25 'Benji' (Biographies of the Qing Emperors), in Er-shi-wu Shi (Twenty-Five Official Histories) (Shanghai: Shanghai Classics Press, 1986), vol. 11, pp. 8827-8937.

Note: Recipient county as the basic accounting unit.

Over the course of its reign, the Qing state managed 1,672-1,704 counties. ${ }^{60}$ As indicated in Table 2, our preliminary observations indicate that all counties were covered 29 times by aid schemes. Densely populated core farming zones received more aid than the periphery (see Table 3 ).

\footnotetext{
58 Pierre-Etienne Will, Bureaucracy and Famine in Eighteenth-Century China (Stanford: Stanford University Press, 1990); Pierre-Etienne Will and R. B. Wong, Nourish the People: the State Civilian Granary System in China, 16501850 (Ann Arbor: University of Michigan Center for Chinese Studies, 1991); Kent Deng, China's Political Economy in Modern Times (London: Routledge, 2011), pp, 19-24.

59 W. J. Peterson (ed.), The Cambridge History of China (Cambridge: Cambridge University Press, 2002), vol. 9, pt. 1, p. 307.

60 Zhao, History of the Qing Dynasty, vols 54-81 'Dili Zhi' (Administrative Geography), in Twenty-Five Official Histories, vol. 11, pp. 9071-9131.
} 
Table 2. Disaster Relief Coverage, 1674-1911

\begin{tabular}{lcccc}
\hline Year & Tax exemptions* & Aid hand-outs* & Total (A)* & A/B $\dagger$ index \\
$1674-1723$ & 3,281 & - & 3,281 & 2.0 \\
$1724-73$ & 9,784 & 6,082 & 15,866 & 9.5 \\
$1774-1823$ & 8,850 & 1,889 & 10,739 & 6.4 \\
$1824-73$ & 7,295 & 3,004 & 10,299 & 6.2 \\
$1874-1911$ & 6,278 & 2,465 & 8,743 & 5.2 \\
Total & 35,443 & 13,440 & 48,883 & 29.2 \\
Annual average & 149.5 & 56.7 & 206.3 & \\
& & & \\
\hline
\end{tabular}

Source: Zhao, History of the Qing Dynasty, vols 4-25 'Benji' (Biographies of the Qing Emperors), in Twenty-Five Official Histories, vol. 11, pp. 8827-8937.

Note: * Total recipient counties. $\uparrow$ Calculated based on 1,672 counties.

Table 3. Provincial Aggregate Disaster-Aid Entries, 1644-1911

Northern core farming provinces

Southern core farming provinces

Northern periphery farming provinces

Southern periphery farming provinces

Non-farming provinces

Total entries

Total shares

\section{Provincial entries $\%$ in China's total}

$\begin{array}{rr}693 & 40.7 \\ 677 & 39.7 \\ 148 & 8.7 \\ 170 & 10.0 \\ 16 & 0.9 \\ 1,704^{*} & \end{array}$

100.00 
Source: Zhao, Draft of the History of the Qing Dynasty, vols 4-25 'Benji' (Biographies of the Qing Emperors) and vols 54-81 'Dili Zhi' (Administrative Geography), in TwentyFive Official Histories), vol. 11, pp. 8827-8937, 9071-9131.61

Note: Northern core farming provinces: Zhili, Henan, Shandong, Shanxi, Shaanxi, and Gansu. Southern core farming provinces: Anhui, Jiangsu, Zhejiang, Hubei, Hunan, Jiangxi, Fujian, Guangdong. Northern periphery farming provinces: Fengtian, Jilin, Heilongjiang, and Xinjiang. Southern periphery farming provinces: Sichuan, Guizhou, Guangxi, Yunnan, and Taiwan. Non-farming provinces: Tibet, Qinghai, Chahar, and Mongolia. * Including country-equivalent units.

The cost of living represents the sixth major factor influencing population. Studies by scholars like Kenneth Pomeranz, Fang Xing, Bozhong Li, Fan Jinmin, and Gao Wangling have indicated that until circa 1850 ordinary rural Chinese lived rather well. ${ }^{62}$ We use food prices and currency purchasing power as proxies for the cost of living. The most complete records of prices are those from the urban market of the Lower Yangtze Valley (see Figure 10).

Figure 10. Average Urban Rice Prices in Jiangsu and Zhejiang, 1740-1910

\footnotetext{
61 Zhao's history is commonly recognised authoritative for the Qing dynasty, ranked equally with all the official histories of the other dynasties.

62 Pomeranz, Kenneth, The Great Divergence, Europe, China and the Making of the Modern World Economy (Princeton: Princeton University Press, 2000), ch. 1; Fang Xing, 'Qingdai Diannongde Zhongnonghua' (Tenants Joining the Middle-Income Group during the Qing Period), Zhongguo Xueshu (Chinese Academics) 2 (2000), pp. 4461; Li Bozhong, 'Rengen Shimu Yu Mingqing Jiangnan Nongminde Jingying Guimo' (The Practice of 'Ten $M u$ per Farmer' and the Scale of the Traditional Peasant Economy), Zhongguo Nongshi (Agricultural History of China), 1 (1996), pp. 1-14; Fan Jinmin, Guoji Minsheng, Mingqing Shehui Jingji Yanjiu (National Economy and People's Livelihood in the Ming-Qing Period) (Fuzhou: Fujian People's Press, 2008); Gao Wangling, Zudian Guanxi Xinlun: Dizhu, Nongmin He Dizu (New Theory of Tenancy: Landlords, Tenants and Rents) (Shanghai: Shanghai Books, 2005).
} 


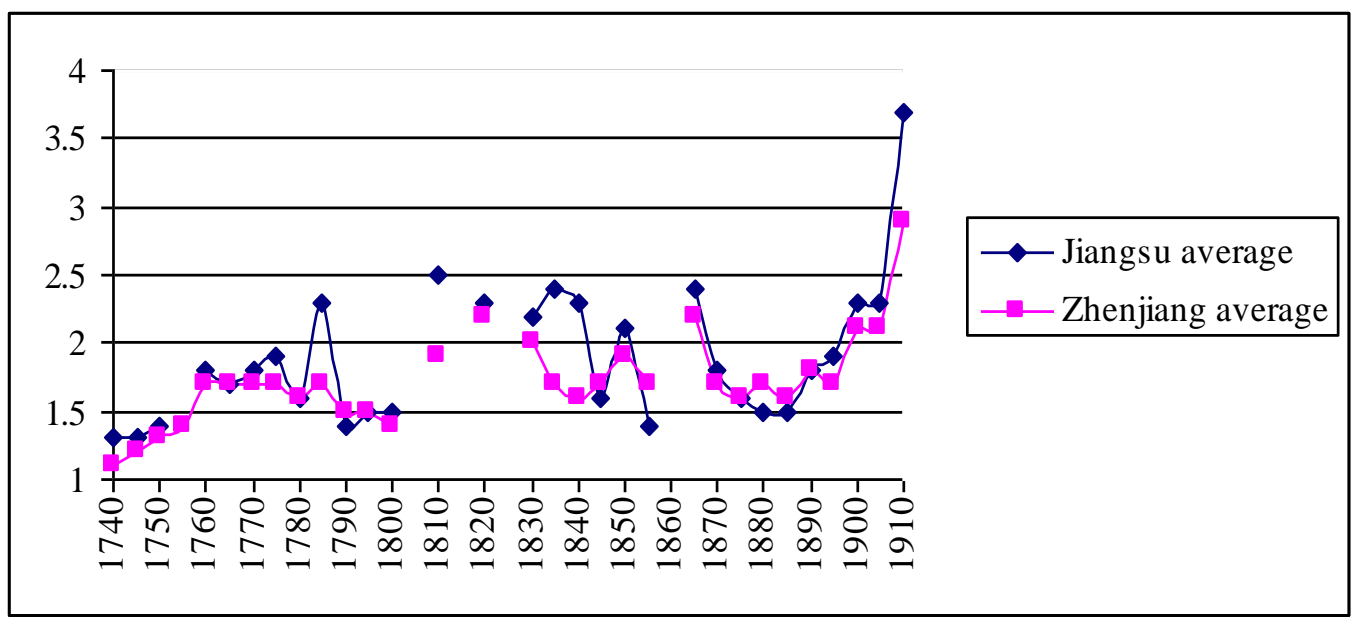

Source: Yejian Wang, The Database of Grain Prices in the Qing Dynasty. Institute of Modern History, Academia Sinica, 2013.

Note: * In amount of silver (taels) per shi of rice. Prices of the Ninth Month when supply was plenty. Locations were the seats of governments of the named prefectures.

Given its use throughout the Qing era as currency, we also construct a silver purchasing power index - measured by amount of rice one tael of silver purchased - to gauge the cost of living (see Figure 11). At first glance, the silver purchasing power index seems to move in the opposite direction of rice prices. This would suggest that the increase in rice prices might have been dictated more by inflations of the silver currency, as opposed to population pressure.

Figure 11. Silver Purchasing Power Index $(1646=100),{ }^{*} 1640-1910$ 


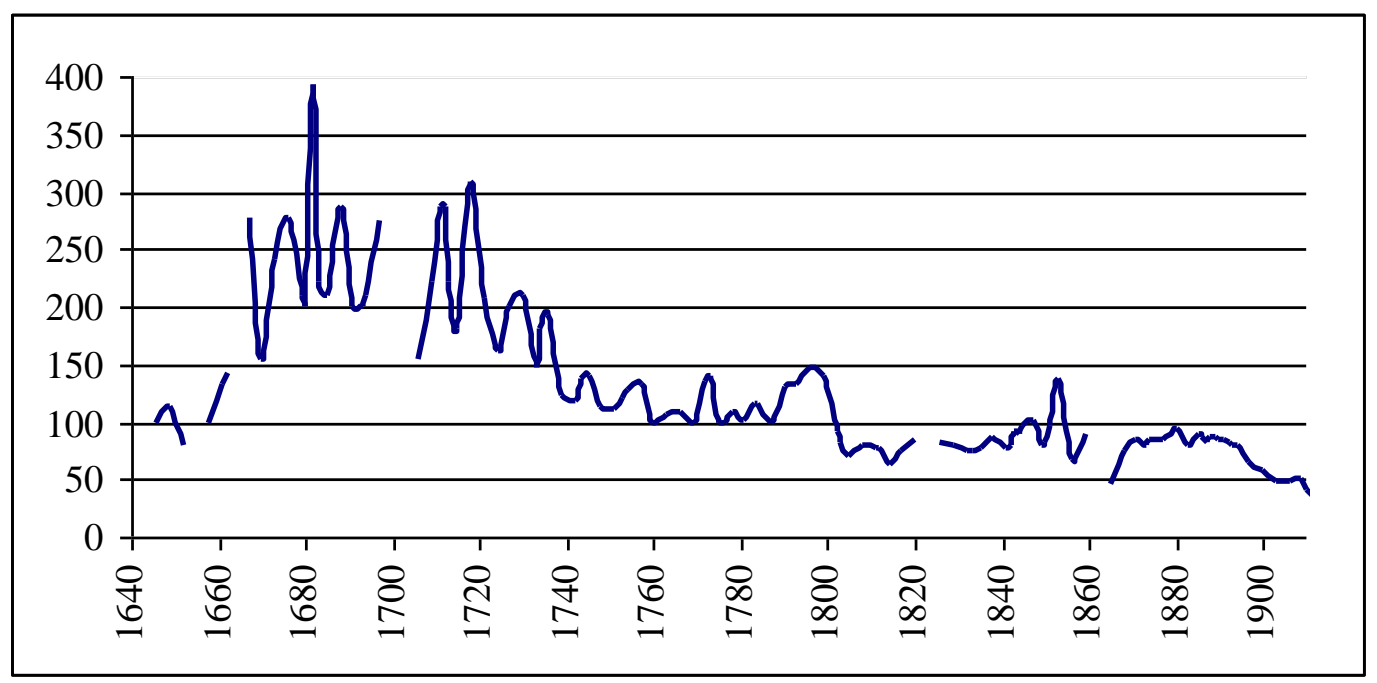

Sources: (1) Before 1693, based on Ye Mengzhu, Yueshi Bian (Record of Life-time Experience in Songjiang) (c. 1688. Reprint. Shanghai: Shanghai Classics Press, 1981), vol.7, pp. 153-4; Yao Tinglin, Linian Ji (Personal Annals) (c. 1698. Reprint. Shanghai: Shanghai People's Press, 1982), pp. 43-156. (2) During 1693-1722, based on Department of Archives, Palace Museum (ed.), Li Xu Zouzhe (Li Xu's Memorials to the Throne) (Beijing: Zhonghua Books, 1976), pp. 1-293. (3) During 1723-35, based on H. S. Chuan and R. A. Kraus, Mid-Ch'ing Rice Markets and Trade: An Essay in Price History (East Asian Research Center, Harvard University, 1975), pp. 145-8. (4) After 1736, based on Wang, The Database of Grain Prices.

Note: * The index represents the amount of rice one silver tael was able to buy. Data are from Jiangsu Province of the Lower Yangtze.

Alternatively, we use the terms of trade between cotton cloth and rice. The cotton cloth price relative to per unit of rice shows a downward trend similar to silver purchasing power index (see Figure 12). There exists no evidence indicating any significant technical progress in cotton farming and cotton textile production to drive relative cotton prices down. ${ }^{63}$ Hence, it is apparent that food became substantively more expensive during the Qing.

\footnotetext{
63 Xu Xinwu, Jiangnan Tubu Shi (A History of Homemade Cotton Cloth in the Lower Yangtze Delta) (Shanghai: Shanghai Social Sciences Press, 1989).
} 
Figure 12. Rice-Cloth Terms of Trade Index $(1700=100),{ }^{*} 1700-1910$

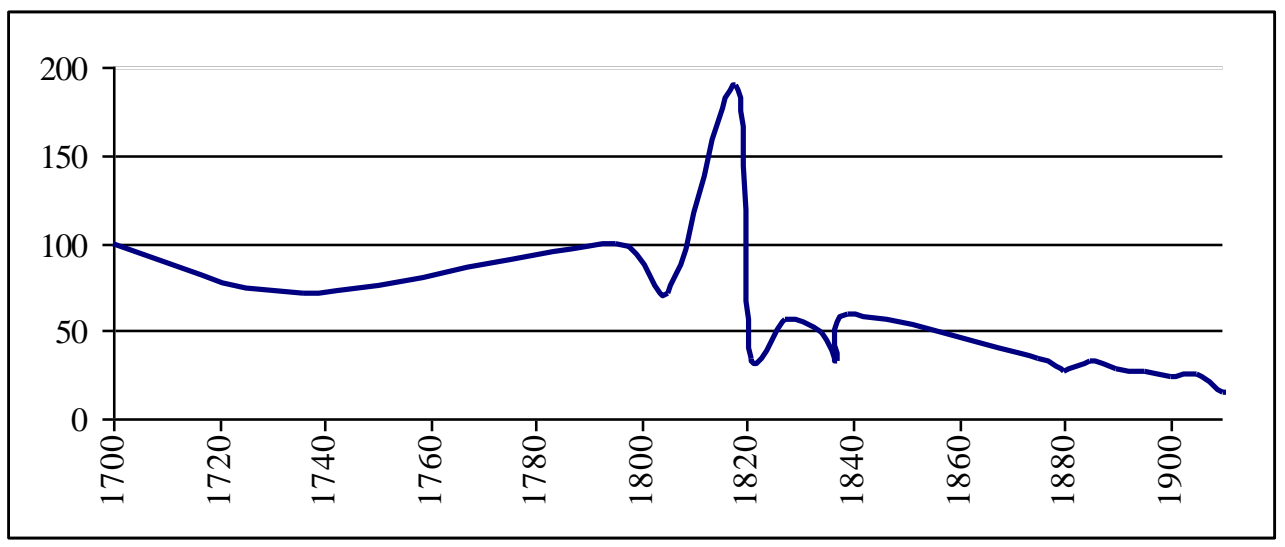

Sources: Huang Miantang, Zhongguo Lidai Wujia Wenti Kaoshu (Study of Prices in China's History over the Long Term) (Jinan: Qilu Books, 2007), pp. 10, 11-12, 47-9, 527, 61-5, 101-7, 109-14, 314, 318-21, 330-3, 336-9; Xu Xinwu, Jiangnan Tubu Shi (A History of Homemade Cotton Cloth in the Lower Yangtze Delta) (Shanghai: Shanghai Academy of Social Science Press, 1989), pp. 176, 201; Yu Yaohua, Zhongguo Jiage Shi (A History of Prices in China) (Beijing: China's Prices Press, 2000), pp. 805, 921-2, 929.64

Note: * Amount of rice (urban prices) per bolt of cotton cloth was able to buy. Cloth here is measured in three zhang per bolt, a common unit for tax payment and domestic trade. Rice means white rice, husked and ready to cook.

Meanwhile, rice prices and population growth moved at the different rates and in different directions (see Figure 13). As such, a more in depth analysis is necessary in order to understand the impact of cost of living on population growth.

Figure 13. Index Values for Changes in Local Population and Urban Rice Prices, 1775/61820

\footnotetext{
64 For much lower cotton cloth pries, see Xu Xinwu, Jiangnan Tubu Shi (A History of Homemade Cotton Cloth in the Lower Yangtze Delta) (Shanghai: Shanghai Academy of Social Science Press, 1989), pp. 92, 94.
} 


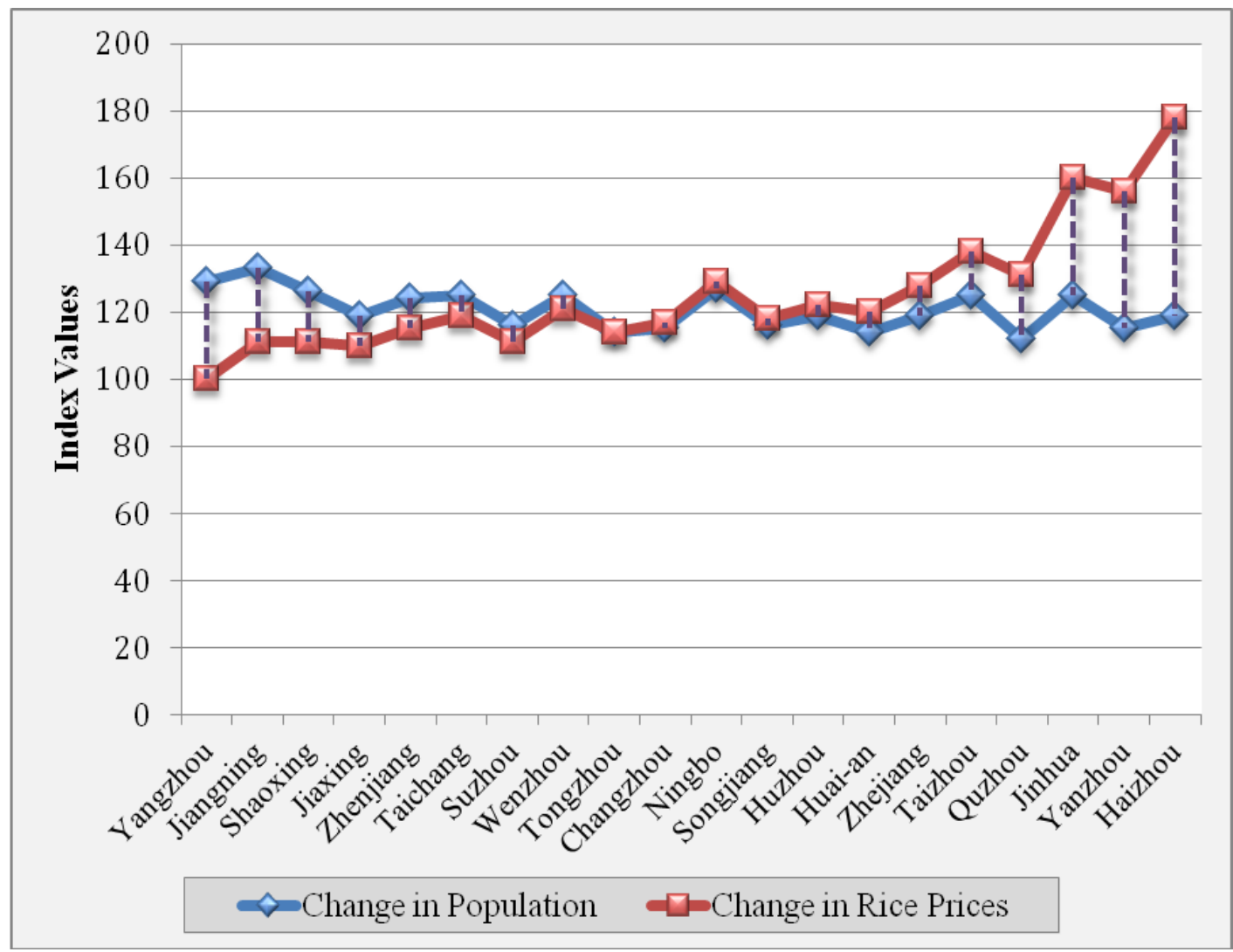

Source: See Table 4.

Note: Prefectures in the Lower Yangtze.

Table 4. Changes in Local Total Population (Both Rural and Urban) and Rice Prices

Prefecture $\quad 1775 / 6(\mathrm{~A}) \quad 1820(\mathrm{~B}) \quad$ Index $(\mathrm{B} / \mathrm{A} \times 100)$
A. Jiangsu Province

1. Changzhou

Population*

311.5

389.6

115

Rice prices $\dagger$

1.8

2.1

117

2. Haizhou

Population*

103.3

122.6

119

Rice prices $\dagger$

1.8

3.2

178

3. Huai-an

Population*

263.0

300.0

114

Rice prices $\dagger$

2.0

2.4

120 
4. Jiangning

Population*

394.1

525.2

133

Rice prices $†$

1.9

2.1

111

5. Songjiang

Population*

227.7

263.2

116

Rice prices $\dagger$

1.7

2.0

118

6. Suzhou

Population*

511.1

116

Rice prices $\dagger$

1.9

590.8

111

7. Taichang

Population*

142.3

177.2

125

Rice prices $\dagger$

2.1

2.5

119

8. Tongzhou

Population*

245.5

280.1

114

Rice prices $\dagger$

2.1

2.4

114

9. Yangzhou

Population*

515.7

666.3

129

Rice prices $\dagger$

2.1

2.1

100

10. Zhenjiang

Population*

177.0

219.5

124

Rice prices $\dagger$

2.0

2.3

115

B. Zhejiang Province

11. Hangzhou

Population*

268.2

319.7

119

Rice prices $\dagger$

1.8

2.3

128

12. Huzhou

Population*

215.3

256.8

119

Rice prices $\dagger$

1.8

2.2

122

13. Jiaxing

Population*

235.3

280.5

119

Rice prices $\dagger$

1.9

2.1

110 
14. Jinhua

$\begin{array}{lrrr}\text { Population* } & 204.8 & 255.0 & 125 \\ \text { Rice prices } \dagger & 1.5 & 2.4 & 160\end{array}$

15. Ningbo

Population*

186.1

235.6

127

Rice prices $\dagger$

2.2

129

16. Quzhou

Population*

102.0

114.1

112

Rice prices $\dagger$

1.6

2.1

131

17. Shaoxing

Population*

426.5

539.2

126

Rice prices $†$

1.9

2.1

111

18. Taizhou

Population*

222.7

277.4

125

Rice prices $\dagger$

1.6

2.2

138

19. Wenzhou

Population*

162.0

201.7

125

Rice prices $†$

1.4

1.7

121

20. Yanzhou

Population*

127.4

146.1

115

Rice prices $\dagger$

1.6

2.5

156

Source: Population data are based on Ge, A Demographic History of China, Vol. 5, pp. $87-8,113$.

Note: $*$ In $10^{4}$ persons. $\dagger$ Silver taels per picul.

Overall, most explanations presented here are based on the back-of-the-envelope style of calculations. The present research seeks to address this issue more comprehensively by employing a quantitative approach that allows for the independent and simultaneous effects of the identified factors to be estimated and analysed. To that end, we have 
developed an extensive dataset drawn from Qing sources. The key data of population, farmland, tax regimes and burden, government revenues and expenditures, food prices, China's territorial borders, and disasters and disaster relief, are extracted from the following authoritative works: Zhao Erxun's Qingshi Gao (Draft of the History of the Qing Dynasty), Liang Fangzhong's Zhongguo Lidai Hukou Tiandi Tianfu Tongji (Dynastic Data for China's Households, Cultivated Land and Land Taxation), Xiang Huaicheng's Zhongguo Caizheng Tongshi (A General History of Government Finance in China), Peng Xinwei's, Zhongguo Houbishi (A History of Currencies in China), H. S. Chuan and R. A. Kraus' Mid-Ch'ing Rice Markets and Trade: An Essay in Price History, Yeh-chien Wang's 'Secular Trends of Rice Prices in the Yangzi Delta, 1638-1935', Yejian Wang's The Database of Grain Prices in the Qing Dynasty, Zhongguo Houbishi (A History of Currencies in China), Tan Qixiang's Jianming Zhongguo Lishi Dituji (Concise Maps of Chinese History), Chen Gaoyong's Zhongguo Lidai Tianzai Renhuo Biao (Chronological Tables of Chinese Natural and Man-made Disasters), and Fu Zhongxia, Zhang Xing, Tian Zhaolin, and Yang Boshi’s Zhongguo Junshi Shi (A Military History of China). All of these works are based on confirmed government records which are commonly regarded as the best available information sources.

Information regarding silver purchasing power comes from local accounts in the Lower Yangtze River: Ye Mengzhu's Yueshi Bian (Record of Life-time Experience in Songjiang), Yao Tinglin's Linian Ji (Personal Annals), and Department of Archives' Li Xu Zouzhe (Li Xu's Memorials to the Throne), H. S. Chuan and R. A. Kraus' Mid-Ch'ing Rice Markets and Trade: An Essay in Price History, Yeh-chien Wang's 'Secular Trends of Rice Prices in the Yangzi Delta, 1638-1935', Yejian Wang's The Database of Grain Prices in the Qing Dynasty, Zhongguo Houbishi (A History of Currencies in China).

Internal migration figures are based on Ge Jianxiong's Zhongguo Yimin Shi (A History of Migration in China), a comprehensive five-volume study based heavily on local government records.

Information on the spread of maize-farming comes from detailed accounts of the adoption of the new crops as recorded in Qing local gazetteers (fangzhi), presented in Xian Jinshan's 'Cong Fangzhi Jizai Kan Yumi Zai Woguode Yinjin He Chuanbo' 
(Adoption and Spread of Maize Seen from Local Gazetteers). Local gazetteers are commonly regarded as a reliable source of information, too.

Qing crop yield levels are based on Shi Zhihong's 'Shijiu Shiji Shangbanqide Zhongguo Liangshi Muchanliang Ji Zongchanliang Zai Guji' (Re-Estimation of Yields per $M u$ and the Aggregate Food Output in Early Nineteenth Century China), a work that systematically tests all the main estimates hitherto. Shi's analysis covers twelve southern provinces (Anhui, Jiangsu, Zhejiang, Hubei, Hunan, Jiangxi, Fujian, Guangdong, Guangxi, Sichuan, Guizhou, Yunnan), enough to serve as a proxy for the improvement in the existing technology in food production. ${ }^{65}$ Shi's yield range is similar to John Buck's comprehensive surveys in the 1920s. ${ }^{66}$ We decide to use Shi's information not only due to its economy-wide vision, but also because of its realistically modest approach compared with many regional 'anecdotes-based' or 'best practice-based' claims. ${ }^{67}$

Due to the lack of data, goods for trade in the Qing economy have to come from estimates. To strike a balance, we compared four major works, two in Chinese and two in English: (1) Wu Chengming's Zhongguode Xiandaihua: Shichang Yu Shehui (China's Modernization: Market and Society), (2) Liu Foding, Wang Yuru and Zhao Jin's Zhongguo Jindai Jingji Fazhan Shi (A History of Economic Development in Early Modern China), (3) Chung-li Chang's The Income of the Chinese Gentry, and (4) Albert Feuerwerker's The Chinese Economy, 1870-1949. However, given that the market share of the Qing economy plays no part in our modelling, any inaccuracy in this respect has no bearing on our analysis.

Table 5 contains a complete list of data sources.

Table 5. Sources of Variables

Variable (Type) Sources

\footnotetext{
65 Note: the average wheat yield level in eight provinces in North China (Zhili, Shandong, Shanxi, Henan, Shaanxi, Gansu, Manchuria, and Xinjiang) did not have much change and is thus unsuited for our purpose.

66 Buck, Land Utilization in China: Atlas, pp. 4, 49.

67 Shi published a new version of in 2015: Shi Zhihong, 'Qingdai Nongye Shengchan Zhibiaode Guji' (Estimation of Rural Production Parameters', Zhongguo Jingjishi Yanjiu (Research into Chinese Economic History) 5 (2015), pp. 5-30. But the genral trend of his two works are the same. We thus stick to his 2012 results.
} 


\begin{tabular}{|c|c|}
\hline Population (LP) (Dependant) & $\begin{array}{l}\text { Qing official figures: Liang, Dynastic Data, p. } \\
\text { 10; Deng, 'Unveiling China's True Population } \\
\text { Statistics', Appendix } 2 .\end{array}$ \\
\hline Farmland, $m u$ (LLA & $\begin{array}{l}\text { Qing official figures: Liang, Dynastic Data } \\
\text { pp. 10, 380, 384, 396, 400, 401. }\end{array}$ \\
\hline $\begin{array}{l}\text { Rice output level (single crop), } \\
\text { dou/mu (LOUTPUT) (Predictor) }\end{array}$ & $\begin{array}{l}\text { Crop yield levels }(\text { dou/mu): Shi Zhihong, 'Re- } \\
\text { Estimation of Yields per } M u \text { and the } \\
\text { Aggregate Food Output in Early Nineteenth } \\
\text { Century China', pp. 52-66. }\end{array}$ \\
\hline $\begin{array}{l}\text { Maize-farming (recipient counties) } \\
\text { (LMAIZE) (Predictor) }\end{array}$ & $\begin{array}{l}\text { Xian, 'Adoption and Spread of Maize Seen } \\
\text { from Local Gazetteers'. }\end{array}$ \\
\hline $\begin{array}{l}\text { Agricultural tax (Land-Poll and } \\
\text { Stipend Rice) (LTAX) (Predictor) }\end{array}$ & $\begin{array}{l}\text { Qing official figures: Liang, Dynastic Data, } \\
\text { pp. 10, 380, 384, 396, 400, 401, 414-16, 482; } \\
\text { also Xiang, A General History of Government } \\
\text { Finance, vol. 8, pp. 78, } 222 .\end{array}$ \\
\hline $\begin{array}{l}\text { Number of disasters and wars } \\
\text { (LWARDI) (Control) }\end{array}$ & $\begin{array}{l}\text { Disasters: Chen, Chronological Tables of } \\
\text { Chinese Natural and Man-Made Disasters. } \\
\text { Wars: Fu et al., A Military History of China, } \\
\text { pp. 65-85. }\end{array}$ \\
\hline $\begin{array}{l}\text { Disaster relief (counting recipient } \\
\text { counties) (LRELIEF) (Control) }\end{array}$ & $\begin{array}{l}\text { Qing official records: Zhao, History of the } \\
\text { Qing Dynasty, vols 4-25 'Benji' (Biographies } \\
\text { of the Qing Emperors), in Twenty-Five } \\
\text { Official Histories, vol. 11, pp. 8827-8937. }\end{array}$ \\
\hline $\begin{array}{l}\text { Prices of rice, taels/shi } \\
\text { (LPRICE) (Control) }\end{array}$ & $\begin{array}{l}\text { Official figures: Wang, 'Secular Trends of } \\
\text { Rice Prices in the Yangzi Delta, 1638-1935'; } \\
\text { Wang, The Database of Grain Prices in the } \\
\text { Qing Dynasty; Peng, A History of Currencies } \\
\text { in China, pp. 824-5, 837, 844, 850-1. }\end{array}$ \\
\hline $\begin{array}{l}\text { Silver purchasing power index } \\
\text { (LINDEX) (Control) }\end{array}$ & $\begin{array}{l}\text { Period information: Ye, Record of Life-time } \\
\text { Experience in Songjiang; Yao, Personal }\end{array}$ \\
\hline
\end{tabular}




\begin{tabular}{l}
\hline \hline Annals; Department of Archives, Palace Museum \\
(ed.), Li Xu's Memorials to the Throne); \\
Wang, Database of Grain. \\
\hline \hline
\end{tabular}

\section{Hypothesis and Modelling}

Our hypothesis is that the sustained population growth during the Qing period was the result of a range of factors: (1) farmland availability, as the main resource base of the economy, (2) crop yield level, which determined a food stock for a population to live on, (3) maize adoption and adaptation, which serves as a proxy for new farming technology, and (4) direct taxes (Land-Poll and Stipend Rice Tax) imposed on land and population, a deduction of wealth from households. Hence, our dependent variable is the growth in population (P); and our four predictors are farmland availability (LAND), crop output level (OUTPUT), maize adoption/adaptation (MAIZE), and agricultural taxes (TAX).

Moreover, we include four control variables in our model. The first control is the combined number of wars and natural disasters to represent shocks on the standing population. The second is the number of counties receiving government disaster-relief to assist the standing population. The third is the price of rice (the primary staple food), which reflects cost of living. Our fourth control is the silver purchasing power index, to check on food prices. In the model these four controls coded as WARDI, RELIEF, PRICE, and INDEX, respectively.

Our population figures are 'numbers of persons' ( $k o u)$ counted by the state. We avoid modern estimates as a matter of principle. ${ }^{68}$ While the accuracy of the official data has

\footnotetext{
68 E.g. China's regional population figures published in Cao Shuji’s Zhongguo Renkou Shi Qing Shiqi (A Demographic History of China, the Qing Period) (Shanghai: Fudan University Press, 2000), which are a mix of sporadic period record and modern estimates. Serious doubts remain regarding the legitimacy of taking estimates for real data, despite the fact that some inspiring works have come out by applying Cao's figures, such as Ruixue Jia, 'Weather Shocks, Sweet Potatoes and Peasant Revolts in Historical China', The Economic Journal, 124/575 (2014), pp. 92-118; Shuo Chen and James Kung, 'Of Maize and Men: The Effect of a New World Crop on Population and Economic Growth in China', Journal of Economic Growth, 12/1 (2016), pp. 71-99.
} 
been questioned, ${ }^{69}$ there has been no independent information to verify either the Qing official data or recent estimates. In terms of farmland, the practice of land acreage conversion (zhe $m u$ ) is well understood, a system under which all farmland was commonly converted into a bench-mark $m u$ for taxation purposes. ${ }^{70}$ Therefore, the $m u$ figures cited in Qing official documents only make sense if one imagines that all the Qing farmland had the identical medium fertility. Figures after official conversion still reflect the size of the Qing resource basis for food production.

Regarding the burden of direct taxes, we incorporate two types of agricultural taxes: (1) the main type called the Land-Poll Combined Tax (diding) collected in silver from all 18 provinces, and (2) the auxiliary type called Stipend Rice Tax (cao mi, cao liang) collected exclusively in grain from 8 provinces along the Grand Canal and its interconnected rivers. ${ }^{71}$ Both direct taxes claimed the lion's share of the Qing government revenue. Given that any cash payment for the Land-Poll Combined Tax usually came from peasant grain sales at market, both taxes must have had the same grain origin. Thus, we convert all the monetary tax payments back to grain (shi) according to the current prices. Our tax burden is measured by tax revenue per $m u$ of farmland to make it agriculture-specific.

Here, a paradox emerges regarding tax payment in food. On the one hand, such payment constituted a deduction of households' food stock which would have otherwise been used to support more children. On the other, food surrendered by the peasantry to the state may not have all been wasted. Rather, it could be consumed by someone else in

\footnotetext{
69 E.g. G. W. Skinner, 'Sichuan's Population in the Nineteenth Century', Late Imperial China, 8/1 (1987), pp. 1-79. Noted, Sichuan during the Qing was one of the 18 provinces. It remains unclear the extent of the problem.

70 Liang, Dynastic Data, p. 528, and Zhao Yun, 'Jishu Wucha, Zhemu Jiqi Juli Shuaijian Guilü Yanjiu' (Technical Errors: Land Unit Conversion and the Law of Diminishing Distance), Zhongguo Shehui Jingjishi Yanjiu (Research into Chinese Social and Economic History), 3 (2007), pp. 1-13; Shi Zhihong, 'Shijiu Shiji Shangbanqide Zhongguo Liangshi Muchanliang Jiqi Zongchanliang Zai Guji' (Re-Estimation of Yields per $M u$ and the Aggregate Food Output in Early Nineteenth Century China), Zhongguo Jingjishi Yanjiu (Research into Chinese Economic History) 3 (2012), p. 55; and Shi Zhihong, 'Qingdai Nongye Shengchan Zhibiaode Guji' (Estimation of Rural Production Parameters', Zhongguo Jingjishi Yanjiu (Research into Chinese Economic History) 5 (2015), pp. 6-7.

${ }^{71}$ Zai Ling, Caoyun Quanshu (Complete Records of Stipend Rice Shipping) (N.d. Reprint. Beijing: Beijing Library Press, no date); Li Wenzhi and Jiang Taixin, Qingdai Caoyun (Stipend Rice during the Qing Period) (Beijing: Zhonghua Books, 1995).
} 
the economy, be they officials, soldiers and artisans. Non-farming families would have babies, too. Therefore, in theory, taxes merely redistributed food instead of destroying it. In reality, however, food was perishable. Regular spoilage during transport and storage was inevitable. In that sense, the deduction was real.

In addition, a farmland-cum-tax regime affected farmers' production perspectives and incentives. It could channel resources to non-food production, and hence reduced food for potential population growth. So, when rural households paid taxes in cash, that cash payment could come from sales of non-food produce which in turn represented opportunity costs for amount of food that would otherwise be produced.

Aside from land taxes, a few minor taxes such as the Salt Tax (yanke) and Customs Duties (guanshui) were imposed during the Qing. There was also the notorious 'Transit Levy' (lijin or likin). But these were indirect taxes and hence linked to consumers' choices and are therefore unsuited for our analysis.

Table 6 contains descriptive statistics of variables before their logarithmic conversion.

Table 6. Descriptive Statistics of Variables

\begin{tabular}{|c|c|c|c|c|c|c|}
\hline Variables & Mean & S.D. & Min & Max & Obs. & Period \\
\hline Population, $10^{6}$ & 237.00 & 14.60 & 38.60 & 39.90 & 118 & $1655-1911$ \\
\hline \multicolumn{7}{|l|}{ Farmland, $10^{6} \mathrm{mu}$} \\
\hline (LAND) & 72.70 & 10.60 & 38.80 & 91.20 & 104 & $1655-1877$ \\
\hline \multirow{2}{*}{\multicolumn{7}{|c|}{$\begin{array}{l}\text { Rice output level, } \\
\text { dou/mu }\end{array}$}} \\
\hline & & & & & & \\
\hline (OUTPUT) & 313.008 & 7.515 & 306 & 321 & 122 & $1646-1911$ \\
\hline \multicolumn{7}{|l|}{ Maize-farming } \\
\hline \multicolumn{7}{|l|}{ (counties) } \\
\hline (MAIZE) & 709.287 & 691.037 & 113 & 1944 & 122 & $1646-1911$ \\
\hline \multicolumn{7}{|l|}{ Disasters and } \\
\hline wars (WARDI) & 13.672 & 8.102 & 2 & 56 & 122 & $1646-1911$ \\
\hline
\end{tabular}


Disaster relief

(counties)

(RELIEF)

$592 \quad 454.675$

0

192990

1646-1911

Rice Prices

taels/shi (PRICE)

1.919

0.906

0.6

$6.2121 \quad 1646-1911$

Silver purchasing

power index

(INDEX)

126.486

67.384

37

$392.2112 \quad 1646-1911$

Agricultural taxes,

in shi (TAX)

0.034

0.016

0.01

0.099102 1661-1906

Source: See Table 5.

Admittedly, the available data in all 77 China-wide observations have some irregular gaps in the time series, ${ }^{72}$ as well as a lack of county-level or prefecture-level information, which limits our choices of analysis, a problem commonly faced by modern researchers. ${ }^{73}$ Technically, we are therefore forced not to carry out the usual tests and analyses, namely, unit root, autocorrelation, Heteroskedasticity and Autocorrelation Consistent Standard Error, de-trended and cointegration analyses. Our second best option is to apply Ordinary Least Squares (OLS) with the Standard Error (SE) to yield robust results instead of perfecting the time series per se (which seems to be an impossible task at the moment due to the information constraint).

\section{Estimation Strategy and Empirical Results}

72 But our data are relatively evenly spread out across the time period in question.

73 E.g. the most recent works by Ruixue Jia, 'Weather Shocks, Sweet Potatoes and Peasant Revolts in Historical China', The Economic Journal 124/575 (2014), pp. 92-118, a work that uses no population datum; Shuo Chen and James Kung, 'Of Maize and Men: The Effect of a New World Crop on Population and Economic Growth in China', Journal of Economic Growth (2016), pp. 1-29, a work that is based on only six population figures; DOI 10.1007/s10887-01609125-8. 
We first conduct an analysis of correlation coefficients of the logged values of one dependent, four explanatory, and four control variables. Doing so suggests potentially high levels of collinearity between LLAND, LTAX, and LPRICE: i.e. the correlation coefficients between LLAND and LTAX, between LTAX and LPRICE, and between LLAND and LPRICE are $-0.7318,-0.9380$ and 0.4861 , respectively. This is well expected, considering (1) the deliberate policy of the Qing state of 'embedding the Poll Tax in farmland' (tanding rumu) and (2) the conversion of tax payment from grain to silver. As a result, we exclude LTAX from modified Models 1 and 2.

The next step in our analysis is to examine the determinants for Qing population growth with a log-linear model with OLS and SE as Model 1:

LP $_{t}=\alpha+\beta_{1}$ LLAND $_{t}+\beta_{2}$ LOUTPUT $_{t}+\beta_{3}$ LMAIZE $_{t}+\beta_{4}$ LWARDI $_{t}+\beta_{5}$ LRELIEF $_{t}+$ $\beta_{6} \mathrm{LPRICE}_{\mathrm{t}}+$ error

To perform more robustness checking, modified Model 2 replaces rice prices (LPRICE $)_{t}$ with silver purchasing power index $\left(\right.$ LINDEX $\left._{t}\right)$ to detect the impact of silver currency on population: ${ }^{74}$

LP $_{t}=\alpha+\beta_{1}$ LLAND $_{t}+\beta_{2}$ LOUTPUT $_{t}+\beta_{3}$ LMAIZE $_{t}+\beta_{4}$ LWARDI $_{t}+\beta_{5}$ LRELIEF $_{t}+$ $\beta_{6}$ LINDEX $_{\mathrm{t}}+$ error

Further, modified Model 3 replaces farmland $\left(L_{L A N D}\right)$ and rice prices $\left(\mathrm{LPRICE}_{\mathrm{t}}\right)$ with taxes $\left(\mathrm{LTAX}_{\mathrm{t}}\right)$ to reveal the impact of taxes on population:

LP $_{t}=\alpha+\beta_{1}$ LOUTPUT $_{t}+\beta_{2}$ LMAIZE $_{t}+\beta_{3}$ LWARDI $_{t}+\beta_{4}$ LRELIEF $_{t}+\beta_{5}$ LTAX $_{t}+$ error

\footnotetext{
74 Rice prices and silver purchasing power are both denominated in the silver currency (taels).
} 
Our results are displayed in Table 7 where Columns (1), (2) and (3) correspond to Models 1, 2 and 3, respectively. As expected, farmland (LLAND $)$, rice output level $\left(\right.$ LOUTPUT $\left._{t}\right)$, adoption of maize-farming $\left(\right.$ LMAIZE $\left._{t}\right)$ and disaster relief $\left(\mathrm{LRELIEF}_{\mathrm{t}}\right)$ are all positively related to population growth $\left(\mathrm{LP}_{\mathrm{t}}\right)$; and disasters and wars $\left(\mathrm{LWARDI}_{\mathrm{t}}\right)$, negatively related to it, ceteris paribus. The high adjusted $\mathrm{R}^{2}$ values indicate that all three models capture most variation of the dependent variable. Moreover, as expected, all coefficients with Model 1 are at the level of 95\% significance or higher. In Models 2 and 3 , silver purchasing power and taxes are negatively related to population on the $1 \%$ significance level.

Table 7. Results with SE

\begin{tabular}{|c|c|c|c|}
\hline & & of Populatio & \\
\hline & (1) & (2) & (3) \\
\hline & 0.910 & 0.676 & \\
\hline Fammanlu (LLAND t) & $(0.340) * * *$ & $(0.364)^{*}$ & \\
\hline & 14.602 & 13.699 & 14.449 \\
\hline & $(2.873) * * *$ & $(2.791) * * *$ & $(2.779) * * *$ \\
\hline & 0.235 & 0.173 & 0.259 \\
\hline & $(0.060) * * *$ & $(0.067)^{* *}$ & $(0.068) * * *$ \\
\hline & -0.226 & -0.216 & -0.265 \\
\hline Disasters and wars (LW AKDIt) & $(0.086) * *$ & $(0.086)^{* *}$ & $(0.091) * * *$ \\
\hline & 0.100 & 0.097 & 0.131 \\
\hline Disaster renter (LKELIEFt) & $(0.034)^{* * *}$ & $(0.032) * * *$ & $(0.032) * * *$ \\
\hline & 0.327 & & \\
\hline KICE prices (LFKICEt) & $(0.110)^{* * *}$ & & \\
\hline & & -0.498 & \\
\hline Sirver s purciasmg power maex (LINDE $\Lambda_{\mathrm{t}}$ ) & & $(0.134) * * *$ & \\
\hline & & & -0.431 \\
\hline 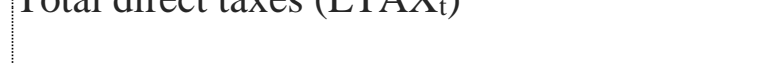 & & & $(0.119) * * *$ \\
\hline Obs & 77 & 71 & 75 \\
\hline
\end{tabular}




\begin{tabular}{|l|lll|}
\hline Adj $R^{2}$ & 0.880 & 0.875 & 0.868 \\
\hline
\end{tabular}

Note: (1) SE readings are in parentheses. (2) ${ }^{* * *},{ }^{* *}$ and ${ }^{*}$ are significant at the $1 \%, 5 \%$ and $10 \%$ levels, respectively.

The impact of either LPRICE $E_{t}$ or LINDEX $_{t}$, is however more complicated. LPRICE $E_{t}$ in Model 1 is positively related to population growth; LINDEX $\mathrm{t}_{\mathrm{t}}$ in Model 2 is negatively related to population growth. This is because the greater the currency's purchasing power, the lower the general price level and hence the lower the cost of living, and vice versa. Thus, the impact of market prices and silver purchasing power moves in opposite directions.

Additionally, a positive correlation between rice prices and population growth seems counter-intuitive. A deeper reason lies in the dualistic nature of China's market in general and its food market in particular during the Qing. Firstly, although some studies have linked commercial expansion with population growth, ${ }^{75}$ the Qing Period was not known for an unusual growth in trade and capitalism. Throughout most of the Qing Dynasty, the share of trade in China's GDP remained tiny: only 5.5 percent of the grain output ever entered the intra-regional commodity chain (see Table 8). ${ }^{76}$ This made the Qing Period very different from the Song (960-1279 AD), when population growth was fuelled by an unprecedented degree of commercialisation and proto-industrialisation. ${ }^{77}$

Table 8. China's Annual Trade in Value, the 1830s

\section{Market value, in tonnes of silver $\%$ in total}

\section{Rural sector}

\footnotetext{
75 Li Bozhong, Duoshijiao Kan Jiangnan Jingjishi, 1250-1850 (Multiple Dimensional View on Economic History of the Jiangnan Region, 1250-1850) (Beijing: Sanlian Books, 2003); Li Bozhong and J. L. van Zanden, 'Before the Great Divergence? Comparing the Yangzi Delta at the Beginning of the Nineteenth Century', Journal of Economic History 72 (2012), pp. 956-90.

76 Wu, Quantitative Studies of Chinese Economic History, pp. 374, 376.

77 K. Deng and L. Zheng, 'Economic Restructuring and Demographic Growth, Demystifying Growth and Development in Northern Song China, 960-1127', Economic History Review, vol. 68, no. 4 (2015), pp. 1107-31.
} 

Grain 78
$6,123.8$
41.0
Cotton fibre and cotton cloth
4027.5
27.0
Tea
$1,196.3$
8.0
Raw silk and silk textiles
997.5
6.7

2. Urban sector

Salt

$2,197.5$

14.7

Porcelain

168.8

1.1

Metals

225.0

1.5

3. Total

$14,936.3$

100.0

4. Trade in GDP

China's total GDP

104,298.8-131,568.8

Trade in total GDP

Of which grain in total GDP

4.7-5.9

Sources: Market values, based on Wu Cengming, Zhongguode Xiandaihua: Shichang Yu Shehui (China's Modernization: Market and Society) (Beijing: Sanlian Books, 2001), pp. 148-9. China's total GDP, based on Chung-li Chang, The Income of the Chinese Gentry (Seattle: University of Washington Press, 1962), p. 296; Albert Feuerwerker, The Chinese Economy, 1870-1949 (Ann Arbor: Center for Chinese Studies of the University of Michigan, 1995), p. 16; Liu Foding, Wang Yuru and Zhao Jin, Zhongguo Jindai Jingji Fazhan Shi (A History of Economic Development in Early Modern China) (Beijing: Tertiary Education Press, 1999), p. 66.

Note: Value in current prices.

Secondly, the food market during the Qing was an urban-specific one. On the demand side, the maximum number of food-market dependent urban residents accounted for

\footnotetext{
78 The figures for grain represent some of the more optimistic estimates; see Yeh-chien Wang, 'Evolution of the Chinese Monetary System, 1644-1850', in Hou Chi-ming, ed., Modern Chinese Economic History (Taipei: The Institute of Economics, Academia Sinica, 1979), pp. 425-56.
} 
about 6-7 percent the Qing total population. ${ }^{79}$ This assessment roughly agrees with the 4.7-5.9 percent of China's total GDP for marketed food (see Table 8).

Of this 6-7 percent, two percent were made of absentee landlords. ${ }^{80}$ These landlords lived on rent paid in kind (mainly food). Roughly, the Qing government-paying employees (both civilian and military) were one million. With their family dependents, they totaled about five million, or another 1.5 percent of the Qing population. The government employee group lived on annual stipends, which came from eight provinces as tax payments. ${ }^{81}$ This left about only 3 percent of the Qing population to urban artisans and the like who lived on commercial food. If so the 4.7-5.9 percent of China's total GDP for marketed food became plenty. Therefore, the Qing urban food market was necessarily very small on both the demand and supply sides. In addition, the 'urban-food-market dependents' (UFMD) were price-takers given that (1) they were unable to alter food supply and, (2) food consumption was price and income inelastic.

Thirdly, China's urban food market may be viewed as an integrated one but only in a relative sense, because local variations were common even in the well inter-connected Lower Yangtze Region (see Figures 14 and 15). ${ }^{82}$ For the vast number of isolated rural

\footnotetext{
79 Ge, A Demographic History of China, Vol. 5, pp. 774, 828-9. Even in the economically-advanced Jiangsu and Zhenjiang Provinces, urbanisation rates were 10-13 percent (circa 1790); see Ge, A Demographic History of China, Vol. 5, pp. 757, 762 .

80 This percentage comes as an average in 89 percent of all provinces of Qing China (16 of 18 provinces); see Fairbank, Cambridge History of China, vol. 12, p. 84.

81 The total number of the Qing troops included 120,000 Eight Banners (baqi) and 660,000 Green Standards (lïying, literarily 'Green Corps'); see Zhao, History of the Qing Dynasty, vol. 131, 'Military', in Twenty-Five Official Histories, vol. 11, pp. 9305, 9307. For the number of salaried officials of 24,150 (c. 1700) to 26,355 (1850), see Yang Zhimei, Xhongguo Gudai Guanzhi Jiangzuo (Bureaucracy of Premodern China) (Beijing: Zhonghua Books, 1992), pp. 420-1. According to Chung-li Chang's, the officials were at one time only 12,000 and no more than 22,830; see Chang, Income, pp. 42, 197, 329-30. The state stipends were fixed at a total of four million piculs (shi) of rice (300,000 tonnes). At the aforementioned minimal food consumption level, four million piculs fed 1.7 million adults, sufficient to cover all the Qing military, officials and their families.

82 For similar plural markets for food during the Qing, see Luo Chang, 'Liangtao Qingdai Liangjia Shuju Ziliaode Bijiao Yu Shiyong' (Comparison and Application of Two Sets of Food Price Data for the Qing Period), Jindaishi Yanjiu (Study of Modern History), 5 (2012), pp. 142-56.
} 
markets, ${ }^{83}$ the neo-classical 'one-price doctrine' did not apply, which means that China's urban rice price was not fit for any China-wide phenomenon.

Figure 14. Urban Rice Prices per Picul (Shi) in Jiangsu Province, 1740-1910

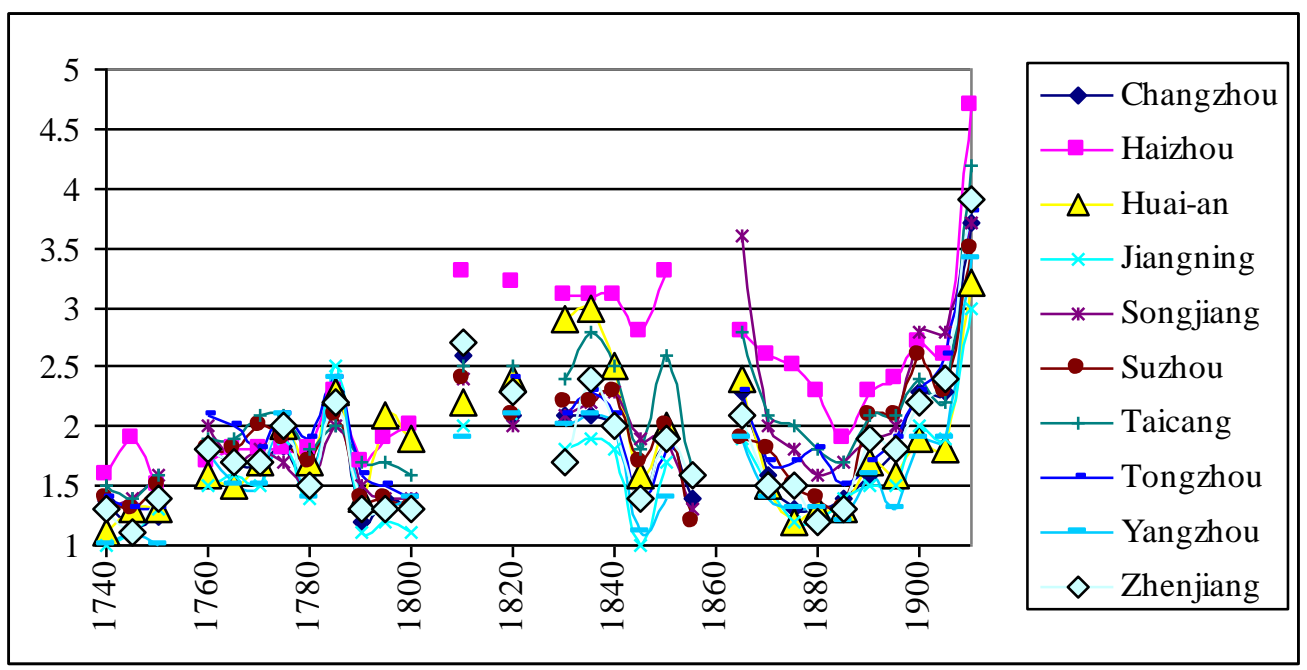

Source: Yejian Wang, The Database of Grain Prices in the Qing Dynasty. Institute of Modern History, Academia Sinica, 2013.

Note: Prices of the Ninth Month, in silver tael. Rice in picul (shi). Locations are seats of governments of named prefectures.

Figure 15. Urban Rice Prices per Picul (Shi) in Zhejiang Province, 1740-1910

\footnotetext{
83 See G. W. Skinner, 'Marketing and Social Structure in Rural China', Journal of Asian Studies, 24 (1964-5), pp. 3-44, 195-228, 363-400; and his The City in Late Imperial China (Stanford: Stanford University Press, 1977).
} 


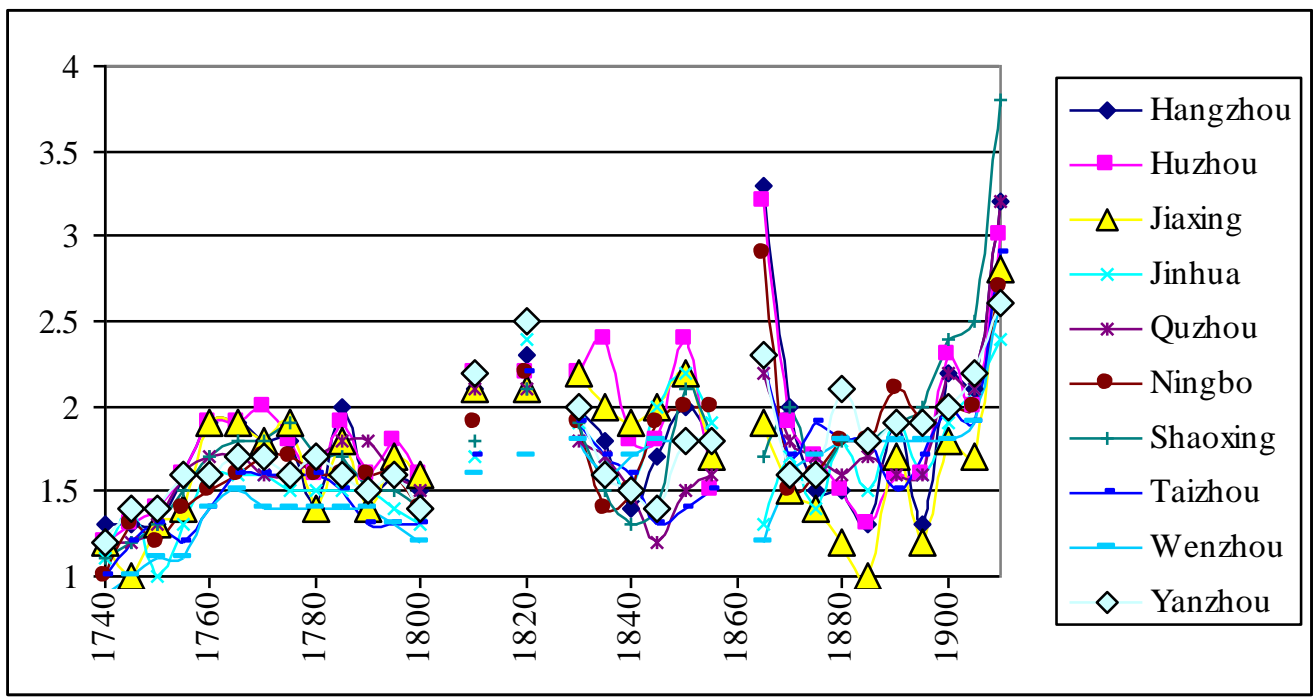

Source: the same as Figure 14.

Note: the same as Figure 14.

Although for half of the urban sector, a high food price led to a high living cost which in turn led to a low living standard and further a low population growth, for all the 'nonurban-food-market dependent population' (NUFMD), a high food price did not change living cost or living standard or propensity for a large family. And NUFMD always formed the vast majority in the Qing population. Moreover, an increase in the urban food price could generate an 'income effect' on NUFMD whose food stock became inflated in value. As a result, an NUFMD household was likely to switch its tax payment from rice to cash if cash payment became cheaper. Many families would respond with more children, too. In this context, therefore, the relationship between living cost (or living standards) and population growth still stands: a low living cost (or a high living standard) supports population growth. So, it was the dualistic nature of the Qing economy that allowed an increase in urban food prices to go hand in hand with a good quality of life in the NUFMD sector. With a 97-to-3 demographic disparity between UFMD and NUFMD, a rise in urban food prices was able to coincide with an increase in the Qing population aggregate.

Figure 16 illustrates this dichotomy, where the Qing economy can be divided into the market and non-market sectors. Conceptually, an initial move comes from an increase in 
food demand in the urban market sector which causes a shift from D to D'. The food price responds to the new demand by moving from $\mathrm{P}_{1}$ to $\mathrm{P}_{2}$ which attracts more food to the market $\left(\mathrm{Q}_{1}\right.$ to $\left.\mathrm{Q}_{2}\right)$. Meanwhile, a high food price increases costs of living in the urban market sector $\left(C_{1}\right.$ to $\left.C_{2}\right)$ which in turn discourages births there $\left(B_{1}\right.$ to $\left.B_{2}\right)$. At the same time, an increased food price has an 'income effect' on NUFMD households' wealth as their existing food stock becomes more valuable than before ( $\mathrm{Y}_{1}$ to $\left.\mathrm{Y}_{2}\right)$, with a virtual gain marked by $\mathrm{Y}_{1} \mathrm{Y}_{2} \delta \gamma$. With the Qing direct tax revenue (the Land-Poll Combined Tax) being frozen at $0 \mathrm{Y}_{0} \lambda \mathrm{Q}^{\prime}{ }_{1}$, there is also some tax payment to be saved and hence the tax obligation now accounts for a smaller share in the households' gross income:

$$
\mathrm{II}+\mathrm{III}\left(0 \mathrm{Y}_{2} \delta \mathrm{Q}^{\prime}{ }_{1}\right)>\mathrm{II}\left(0 \mathrm{Y}_{1} \gamma \mathrm{Q}^{\prime}{ }_{1}\right)
$$

Hence,

$$
\text { I }\left(0 \mathrm{Y}_{0} \lambda \mathrm{Q}^{\prime}\right): \text { II + III }<\text { I }: \text { II }
$$

Figure 16. Dual Sectors of the Qing Economy 


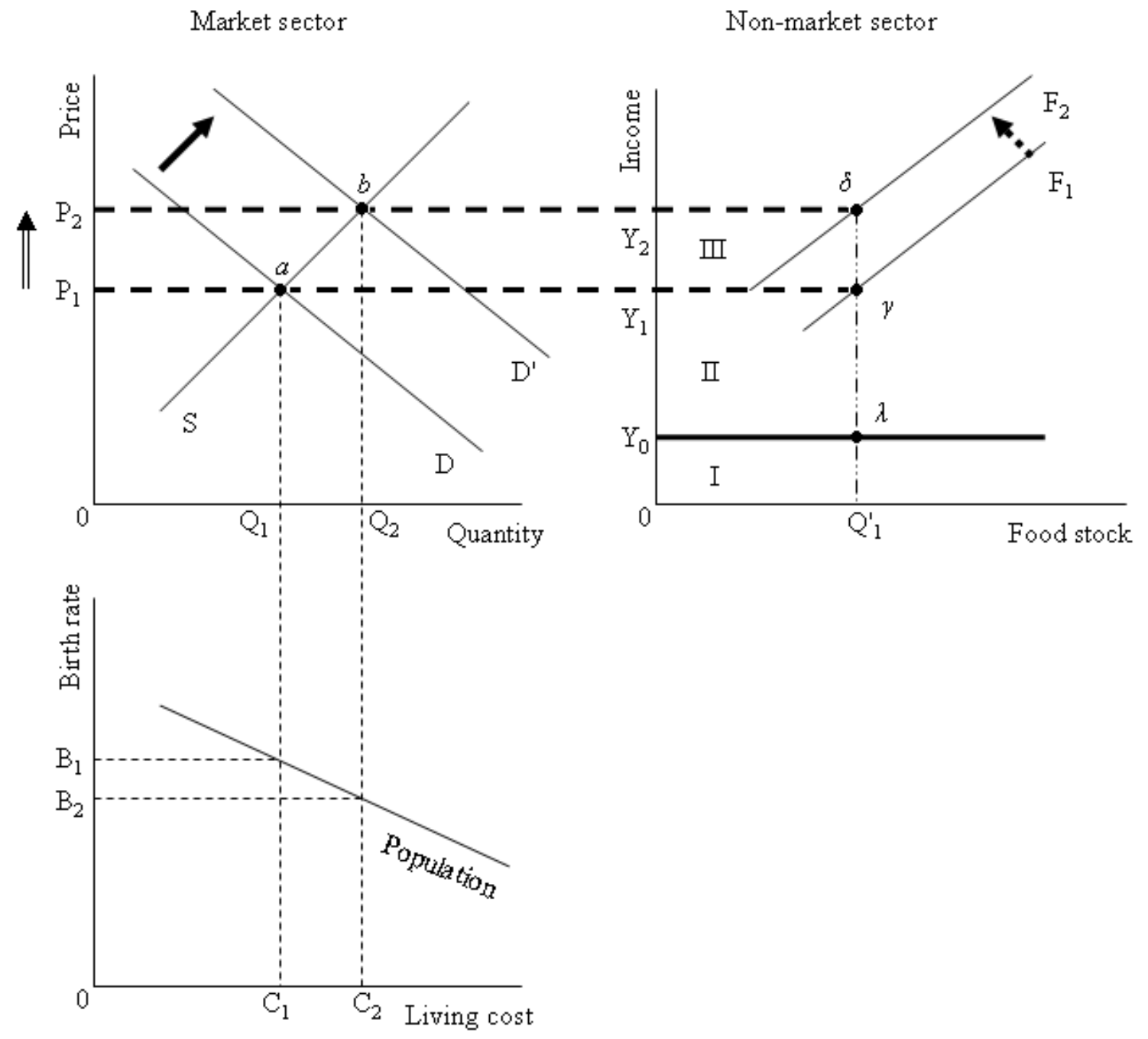

Note: Points $a, b, \gamma, \delta, \lambda$ are equilibria. The solid arrow represents the initial move of the market demand curve, the hollow arrow represents a subsequent change in market food prices, the dash arrow represents 'income effect of changed food prices' in the nonmarket sector, thick dash lines represent key linkages between the two sectors, and the thick line represents a reduction in income from direct taxes. Areas I, II, and III represent different components of households' gross income.

Rural households' net wealth thus moves from $\mathrm{W}_{0}-\mathrm{W}_{1}$ to $\mathrm{W}_{0^{-}}-\mathrm{W}_{2}$, a situation which encourages births $\left(\mathrm{P}_{1}\right.$ to $\left.\mathrm{P}_{2}\right)$, as shown in Figure 17.

Figure 17. Impact on the Non-Market Sector 


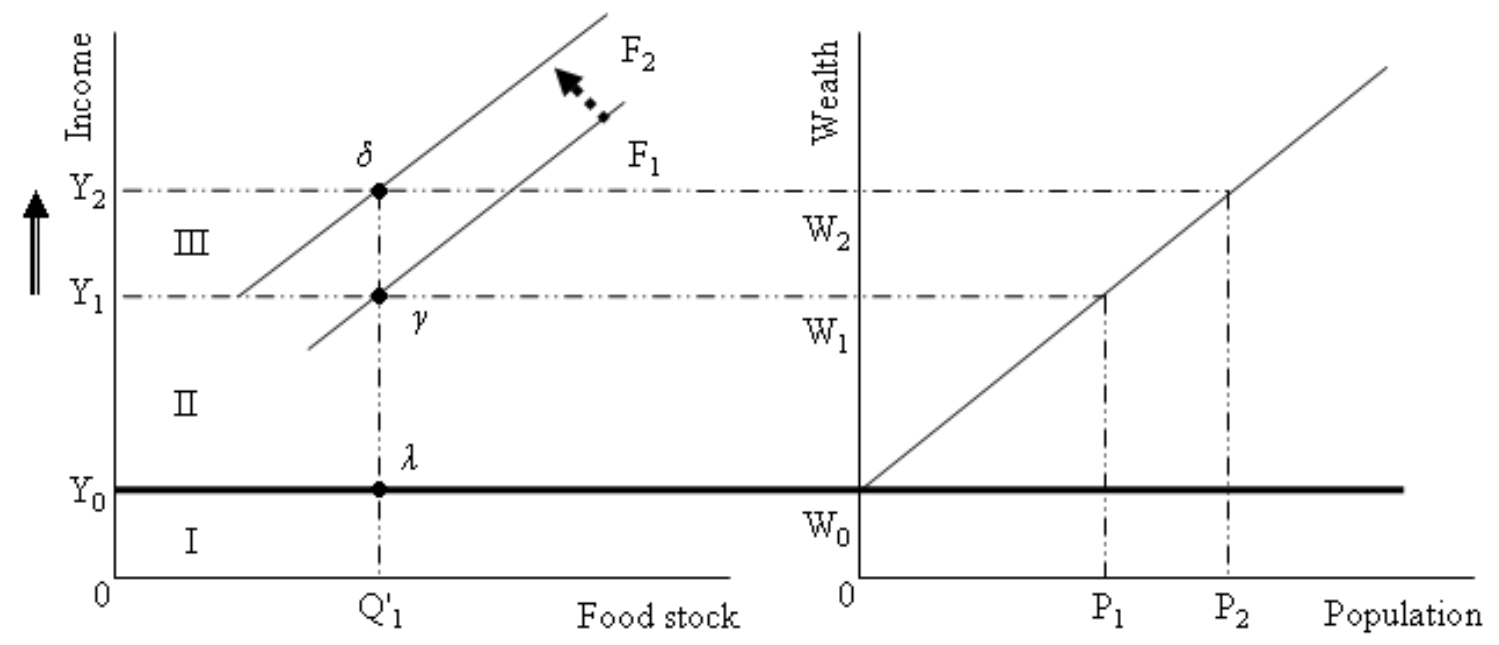

Note: Points $a, b, \gamma, \delta, \lambda$ are equilibria. $0-\mathrm{Y}_{0}$ and $0-\mathrm{W}_{0}$ show income deduction due to taxes. The hollow arrow represents a subsequent change in market food prices, and the dash arrow represents 'income effect of changed food prices' in the non-market sector, Areas I, II, and III represent different components of households' gross income.

This study is the first one to differentiate the dualistic impact of food prices on sectoral population growths in China. With this approach, a positive relationship between urban rice prices and overall population growth can be well justified.

Given that there exists the possibility that causation could run from the dependent variable to the independent variables, we repeat all three models with lagged values with SE for all independent variables: (1) Model 1 includes farmland (LLAND $\mathrm{t}_{\mathrm{t}-1}$ ), rice output level (LOUTPUT $\left.T_{t-1}\right)$, adoption of maize $\left(\right.$ LMAIZE $\left._{t-1}\right)$, disaster relief $\left(\mathrm{LRELIEF}_{\mathrm{t}-1}\right)$, rice prices (LPRICE $\left.{ }_{t-1}\right)$; (2) Model 2 adds silver purchasing power index (LINDEX $\left.\mathrm{t}_{\mathrm{t}-1}\right)$; (3) Model 3 embraces agricultural direct taxes $\left(\operatorname{LTAX}_{\mathrm{t}-1}\right)$. Since wars and disasters (LWARDI) usually had their impact on population in real time, a time lag cannot apply.

The results of Model 1 with a time lag (TL) shown in Columns (4) to (9) of Table 9; those of Model 2 (with lagged LINDEX $\mathrm{t}_{-1}$ ), in Column (10) of Table 9; and those of Model 3 (with lagged LTAX ), in Table 10. 
Table 9. Results of Models 1 and 2 with TL and SE

\begin{tabular}{|c|c|c|c|c|c|c|c|}
\hline & \multicolumn{7}{|c|}{ Population growth } \\
\hline & (4) & (5) & (6) & (7) & $(8)$ & (9) & (10) \\
\hline \multirow{2}{*}{ LLAND } & & 0.874 & 0.877 & 0.865 & 1.003 & & \\
\hline & & $(0.349) * *$ & $(0.353) * *$ & $(0.323) * * *$ & $(0.332) * * *$ & & \\
\hline \multirow{2}{*}{ LLAND $_{\mathrm{t}-1}$} & 0.565 & & & & & 0.943 & 0.783 \\
\hline & $(0.271)^{* *}$ & & & & & $(0.297) * * *$ & $(0.368) * *$ \\
\hline \multirow{2}{*}{ LOUTPUT } & 14.526 & & 14.732 & 13.414 & 14.436 & & \\
\hline & $(2.729) * * *$ & & $(2.752) * * *$ & $(2.860) * * *$ & $(2.879) * * *$ & & \\
\hline \multirow{2}{*}{ LOUTPUT $_{\mathrm{t}-1}$} & & 13.776 & & & & 12.716 & 11.745 \\
\hline & & \multicolumn{2}{|l|}{$(2.951) * * *$} & & & $(2.992) * * *$ & $(2.889) * * *$ \\
\hline \multirow{2}{*}{ LMAIZE } & 0.232 & 0.275 & & 0.240 & 0.237 & & \\
\hline & $(0.059)^{* * *}$ & $(0.068)^{* * *}$ & & $(0.063) * * *$ & $(0.061)^{* * *}$ & & \\
\hline \multirow{2}{*}{ LMAIZE $_{\mathrm{t}-1}$} & & & 0.243 & & & 0.257 & 0.193 \\
\hline & & & \multicolumn{2}{|l|}{$(0.059) * * *$} & & $(0.064) * * *$ & $(0.068) * * *$ \\
\hline \multirow{2}{*}{ LWARDI } & -0.233 & -0.224 & -0.217 & -0.234 & -0.200 & -0.162 & -0.152 \\
\hline & $(0.086)^{* * * *}$ & $(0.088) * *$ & $(0.085)^{* *}$ & $(0.077) * * *$ & $(0.083) * *$ & $(0.077) * *$ & $(0.078) *$ \\
\hline \multirow{2}{*}{ LRELIEF } & 0.102 & 0.113 & 0.104 & & 0.097 & & \\
\hline & $(0.032)^{* * *}$ & $(0.038) * * *$ & $(0.034) * * *$ & & $(0.033) * * *$ & & \\
\hline \multirow{2}{*}{ LRELIEF $_{\mathrm{t}-1}$} & & & & 0.098 & & 0.090 & 0.083 \\
\hline & & & & \multicolumn{2}{|l|}{$(0.034) * * *$} & $(0.037)^{* *}$ & $(0.036) * *$ \\
\hline \multirow{2}{*}{ LPRICE } & 0.415 & 0.278 & 0.330 & 0.318 & & & \\
\hline & $(0.110)^{* * *}$ & $(0.122) * *$ & $(0.109)^{* * *}$ & $(0.103) * * *$ & & & \\
\hline \multirow{2}{*}{ LPRICE $_{\mathrm{t}-1}$} & & & & & 0.332 & 0.322 & \\
\hline & & & & & $(0.102) * * *$ & $(0.105) * * *$ & \\
\hline \multirow{2}{*}{ LINDEX $_{\mathrm{t}-1}$} & & & & & & & -0.503 \\
\hline & & & & & & & $(0.126) * * *$ \\
\hline Obs & 76 & 77 & 77 & 77 & 77 & 77 & 71 \\
\hline Adj $R^{2}$ & 0.884 & 0.874 & 0.881 & 0.883 & 0.882 & 0.872 & 0.868 \\
\hline
\end{tabular}


Note: (1) SE readings of SE are in parentheses. (2) ${ }^{* * *},{ }^{* *}$ and $*$ are significant at the $1 \%$, $5 \%$ and $10 \%$ levels, respectively.

Table 10. Results of Model 3 with TL and SE

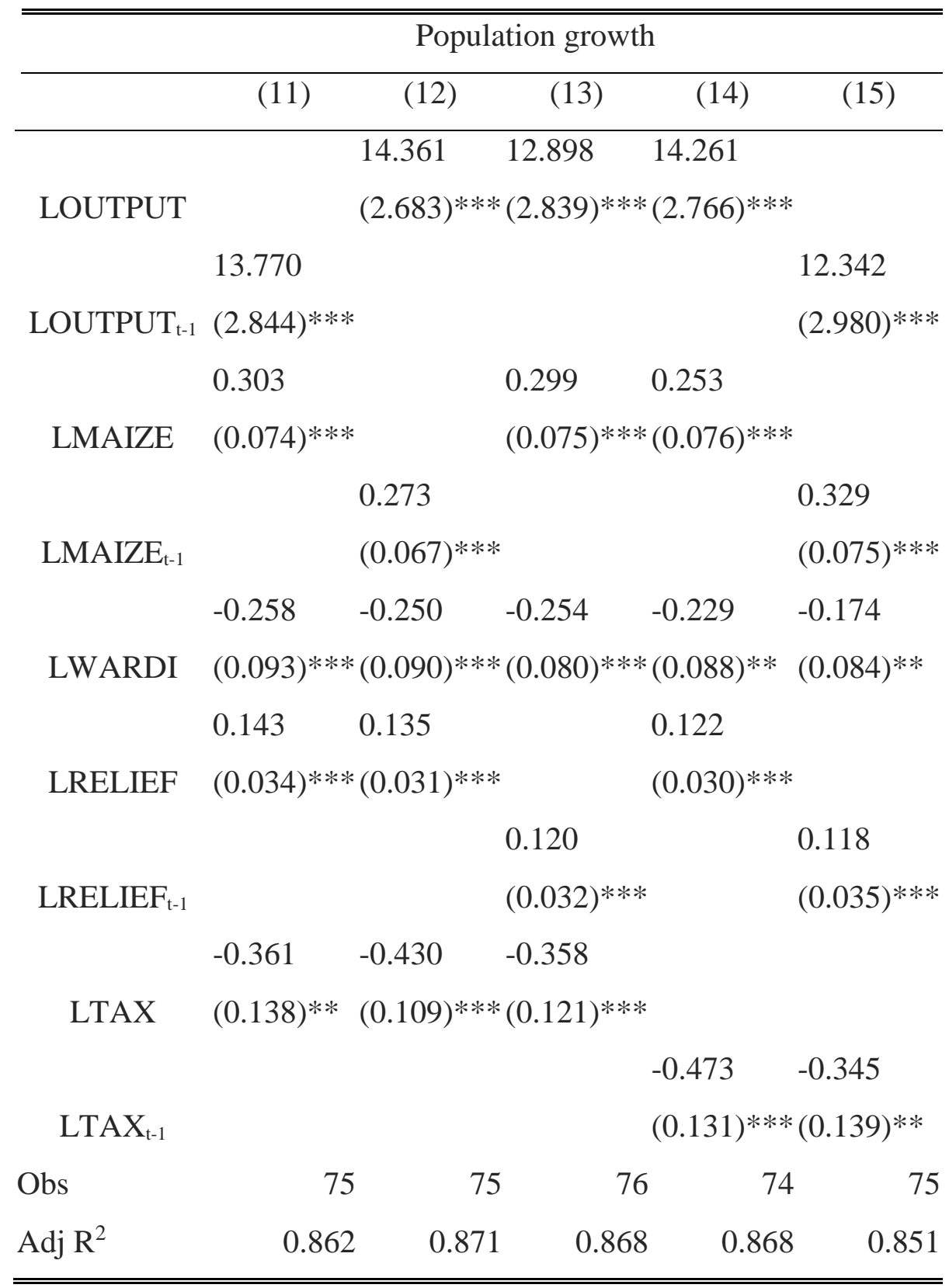

Note: (1) SE readings are in parentheses. (2) ${ }^{* * *},{ }^{* *}$ and ${ }^{*}$ are significant at the $1 \%, 5 \%$ and $10 \%$ levels, respectively. 
The results of the modelling specifications 1,2 and 3 with a time lag are very similar to the modelling specifications without lags. This warrants a low risk of bi-directional causality between the dependent and independent variables.

To summaries, Table 7 indicates that all eight predictor variables (see Table 6) were important for population growth. Farmland $\left(\mathrm{LLAND}_{\mathrm{t}}\right)$, rice output level $\left(\mathrm{LOUTPUT}_{\mathrm{t}}\right.$ ), maize-farming $\left(\mathrm{LMAIZE}_{\mathrm{t}}\right)$ and disaster relief $\left(\mathrm{LRELIEF}_{\mathrm{t}}\right)$ had positive and significant impact on population growth. The effect of rice output level on population growth was substantial. The second important factor went to farmland, followed by rice prices, adoption of new technology, and then disaster relief. Overall, improvements in technology mattered. In this context, a significant amount of 'free lunches' still existed in the Qing economy. ${ }^{84}$ On the institutional front, the Qing proto-welfare state that expanded farmland (migration embedded) and minimised population losses also played a positive role in population growth. ${ }^{85}$ Exogenous shocks of wars and disasters (LWARDI) had a significant but negative influence on population growth, as did taxes (LTAX). The negative impact of the tax burden was greater than that of wars and disasters, despite the fact that the Qing tax burden per $m u$ was the lightest hitherto in China's long history. Finally, rice prices (LPRICE) had positive and significant impact while the silver purchasing power index (LINDEX) had negative and significant impact on population growth due to the urban bias towards rice prices.

\section{Conclusions}

In this study, we establish a historical time series to model China's unprecedented population expansion during the Qing Period and apply OLS with SE and TL to ascertain correlations between a variety of factors and population growth. The results warrant a high degree of robustness and a low risk of bi-directional causality.

\footnotetext{
84 Joel Mokyr, The Lever of Riches (New York and Oxford: Oxford University Press, 1990), ch. 1.

85 Will, Bureaucracy and Famine; Will and Wong, Nourish the People; Deng, The Premodern Chinese Economy, chs $1-3$.
} 
Our findings reveal that the extraordinary growth in China's population during the Qing Period was supported by, in the order of weight and importance (1) availability of farming technology, (2) elastic supply of farmland, and (3) disaster relief provision.

Wars and disasters, and tax burden had a negative impact on population growth. Even so, the unique combination of increased farmland and capped agricultural direct taxes led to a steady decline in the tax burden on per unit of land, which softened the negative impact of taxation on population growth.

It becomes also clear that to a great extent, the extraordinary population growth experienced in Qing China was mainly propelled by the non-market sector, which responded to food prices very differently from its market counterpart.

Admittedly, out research is limited on the macro-level with an economy-wide approach, which only serves the purpose when the Qing economy is conceptually taken as one entity. We certainly hope that primary-source data for a micro-level become also available one-day to facilitate more empirical studies of the Qing population.

\section{Bibliography}

Anon., Qing Gaozong Shilu (Veritable Records of Emperor Gaozong of the Qing Dynasty) (1799. Reprint. Taipei: Hualian Press, 1964).

Boserup, Ester, The Conditions of Agricultural Growth: The Economies of Agrarian Change under Population Pressure (London: Allen and Unwin, 1965).

Bray, Francesca, The Rice Economies, Technology and Development in Asian Societies (Oxford: Blackwell, 1986).

Buck, J. L., Land Utilization in China: Atlas (London: Oxford University Press, 1937). Cao Shuji, Zhongguo Renkou Shi Mingqing Shiqi (A Demographic History of China, the Qing Ming Period) (Shanghai: Fudan University Press, 2000).

Cao Shuji, Zhongguo Renkou Shi Qing Shiqi (A Demographic History of China, the Qing Period) (Shanghai: Fudan University Press, 2000).

Chang, Chung-li, The Chinese Gentry: Studies on Their Role in Nineteenth-Century Chinese Society (Seattle: University of Washington Press, 1955). 
Chang, Chung-li, The Income of the Chinese Gentry (Seattle: University of Washington Press, 1962).

Chao, Kang, Man and Land in Chinese History: An Economic Analysis (Stanford: Stanford University Press, 1986).

Chen Chunsheng and Liu Zhiwei, 'Qingdai Jingji Yunzuode Liangge Tedian' (Two Characteristics of Qing Economic Operation), Zhongguo Jingjishi Yanjiu (Research into Chinese Economic History), 3 (1990), pp. 84-9.

Chen Gaoyong, Zhongguo Lidai Tianzai Renhuo Biao (Chronological Tables of Chinese Natural and Man-made Disasters) (Shanghai: Jinan University Press, 1937).

Chen Hua, Qingdai Quyu Shehui Jingji Yanjiu (Regional Socio-Economic Conditions during the Qing Period) (Beijing: People's University Press, 1996).

Chen Shuping, 'Yumi He Fanshu Zai Zhongguo Chuanbo Qingkuang Yanjiu' (Studies of the Spread of Maize and Sweet Potatoes in China), Zhongguo Shehui Kexue (Social Sciences in China), 3 (1980), pp. 188-204.

Chen, Shuo and James Kung, 'Of Maize and Men: The Effect of a New World Crop on Population and Economic Growth in China', Journal of Economic Growth, 12/1 (2016), pp. 71-99.

Chuan, H. S. and R. A. Kraus, Mid-Ch'ing Rice Markets and Trade: An Essay in Price History. East Asian Research Center, Harvard University, 1975.

Deng Ciyu, Zhongguo Kaoshi Zhidu Shi (History of the Chinese Imperial Examination System) (Taipei: Xuesheng Books, 1967).

Deng, Gang, The Premodern Chinese Economy - Structural Equilibrium and Capitalist Sterility (London and New York: Routledge, 1999).

Deng, Kent and Lucy Zheng, 'Economic Restructuring and Demographic Growth, Demystifying Growth and Development in Northern Song China, 960-1127', Economic History Review, vol. 68, no. 4 (2105), pp. 1107-31.

Deng, Kent, 'Unveiling China's True Population Statistics for the Pre-Modern Era with Official Census Data', Population Review 43/2 (2004), pp. 1-38.

Deng, Kent, China's Political Economy in Modern Times (London: Routledge, 2011).

Department of Archives, Palace Museum (ed.), Li Xu Zouzhe (Li Xu's Memorials to the Throne) (Beijing: Zhonghua Books, 1976). 
Durand, J. D., 'The Population Statistics of China, A.D. 2-1953'. Population Studies, 13 (1960), pp. 209-57.

Elvin, Mark, The Pattern of the Chinese Past (Stanford: Stanford University Press, 1973).

Fairbank, J. K. and Kwang-ching Liu (eds), Cambridge History of China, Late Ch'ing, 1800-1911, Part II (Cambridge: Cambridge University Press, 1980).

Fairbank, J. K. and Merle Goldman, China: A New History (Harvard University Press, 2005).

Fairbank, J. K., Chinese Thought and Institutions (Chicago: Chicago University Press, 1957).

Fan Jinmin, Guoji Minsheng, Mingqing Shehui Jingji Yanjiu (National Economy and People's Livelihood in the Ming-Qing Period) (Fuzhou: Fujian People's Press, 2008).

Fang Xing, 'Qingdai Diannongde Zhongnonghua' (Tenants Joining the Middle-Income Group during the Qing Period), Zhongguo Xueshu (Chinese Academics) 2 (2000), pp. 44-61.

Feuerwerker, Albert, The Chinese Economy, 1870-1949 (Ann Arbor: Center for Chinese Studies of the University of Michigan, 1995).

Fu Zhongxia, Zhang Xing, Tian Zhaolin, and Yang Boshi, Zhongguo Junshi Shi (A Military History of China) (Beijing: PLA Press, 1986).

Gao Wangling, Zudian Guanxi Xinlun: Dizhu, Nongmin He Dizu (New Theory of Tenancy: Landlords, Tenants and Rents) (Shanghai: Shanghai Books, 2005).

Ge Jianxion, Minzu Da Qianxi (Ethnic Exodus) (Hong Kong: Zhonghua Books, 2014).

Ge Jianxiong (ed.), Zhongguo Yimin Shi (A History of Migration in China) (Fuzhou: Fujian People's Press, 1997).

Ge Jianxiong, Zhongguo Renkou Shi - Qing Shiqi (A Demographic History of China, Vol. 5, the Qing Period) (Shanghai: Fudan University Press, 2000).

Guo Wentao, Zhongguo Nongyie Keji Fazhan Shilue (A Brief History of Development of Agricultural Science and Technology in China) (Beijing: Chinese Science and Technology Press, 1988).

Ho, Ping-ti, Studies on the Population of China, 1368-1953 (Cambridge [Mass.]: Harvard University Press, 1959). 
Ho, Ping-ti, The Ladder of Success in Imperial China (New York: Columbia University Press, 1962).

Huang Miantang, Zhongguo Lidai Wujia Wenti Kaoshu (Study of Prices in China's History over the Long Term) (Jinan: Qilu Books, 2007).

Huang, Philip, The Peasant Economy and Social Change in North China (Stanford: Stanford University Press, 1985).

Jia, Ruixue, 'Weather Shocks, Sweet Potatoes and Peasant Revolts in Historical China', The Economic Journal, 124/575 (2014), pp. 92-118.

Jiang Tao, Lishi Yu Renkou - Zhongguo Chuantong Renkou Jieguo Yanjiu (History and Demography - China's Traditional Demographic Pattern) (Beijing: People's Press, 1998).

Jiang Tao, Renkou Yu Lishi, Zhongguo Chuantong Renkou Jiego Yanjiu (Population and History, A Study of Chinese Traditional Demographic Structure) (Beijing: People's Press, 1998).

Lavely, William and R. Bin. Wong, 'Revising the Malthusian Narrative: the Comparative Study of Population Dynamics in Late Imperial China', The Journal of Asian Studies, 57/3 (1998), pp. 714-48.

Lee, James and Cameron Campbell, Fate and Fortune in Rural China (Cambridge: Cambridge University Press, 1997).

Lee, James and Wang Feng, One Quarter of Humanity (Cambridge [ MA]: Harvard University Press, 1999).

Lee, James, 'Population Growth in Southwest China, 1250-1850', The Journal of Asian Studies, 41/4 (1982), pp. 711-46.

Lee, James, Cameron Campbell, and Guofu Tan, 'Infanticide and Family Planning in Late Imperial China', in Thomas Rawski and Lillian Li, eds., Chinese History in Economic Perspective (Berkeley: University of California Press, 1992), pp. 145-76.

Leonard, J. K. and J. R. Watt (eds.), To Achieve Security and Wealth (Ithaca: Cornell University East Asia Program, 1992).

Li Bozhong and J. L. van Zanden, 'Before the Great Divergence? Comparing the Yangzi Delta at the Beginning of the Nineteenth Century', Journal of Economic History 72 (2012), pp. 956-90. 
Li Bozhong, 'Qingdai Qianzhongqi Jiangnan Renkode Disu Zengzhang Jiqi Yuanyin' ('The Low Population Growth in the Yangtze Delta and its Reason during Early and Mid-Qing Times'), Qingshi Yanjiu (Study of Qing History), 2 (1996), pp. 10-19.

Li Bozhong, 'Rengen Shimu Yu Mingqing Jiangnan Nongminde Jingying Guimo' (The Practice of 'Ten $M u$ per Farmer' and the Scale of the Traditional Peasant Economy), Zhongguo Nongshi (Agricultural History of China), 1 (1996), pp. 1-14.

Li Bozhong, Duoshijiao Kan Jiangnan Jingjishi, 1250-1850 (Multiple Dimensional View on Economic History of the Jiangnan Region, 1250-1850) (Beijing: Sanlian Books, 2003).

Li Shizhen, Compendium of Materia Medica (Bencao Gangmu) (1578. Reprint. Beijing: People's Press, 1977).

Li Wenzhi and Jiang Taixin, Qingdai Caoyun (Stipend Rice during the Qing Period) (Beijing: Zhonghua Books, 1995).

Liang Fangzhong, Zhongguo Lidai Hukou Tiandi Tianfu Tongji (Dynastic Data for China's Households, Cultivated Land and Land Taxation) (Shanghai: Shanghai People's Press, 1980).

Liu Foding, Wang Yuru and Zhao Jin, Zhongguo Jindai Jingji Fazhan Shi (A History of Economic Development in Early Modern China) (Beijing: Tertiary Education Press, 1999).

Luo Chang, 'Liangtao Qingdai Liangjia Shuju Ziliaode Bijiao Yu Shiyong' (Comparison and Application of Two Sets of Food Price Data for the Qing Period), Jindaishi Yanjiu (Study of Modern History), 5 (2012), pp. 142-56.

Maddison, Angus, Chinese Economic Performance in the Long Run (Paris: OECD, 1998).

Martini, Martino, De Bello Tartarica Historia (Antwerp, 1654), vide: en.wikipedia.org, available on 20 February 2018.

McEvedy, Colin and Richard Jones (eds), Atlas of World Population History (Harmondsworth: Penguin Books, 1978).

Mokyr, Joel, The Lever of Riches (New York and Oxford: Oxford University Press, 1990). 
Mote, F. W., Imperial China, 900-1800 (Cambridge [MA]: Harvard University Press, 1999).

Myers, R. H., The Chinese Peasant Economy: Agricultural Development in Hopei and Shangtung, 1890-1949 (Cambridge [MA]: Harvard University Press, 1970).

Nieuhof, John, Voyages \& Travels to the East Indies 1653-1670 (Reprint, Oxford: Oxford University Press, 1988).

Peng Xinwei, Zhongguo Houbishi (A History of Currencies in China) (Shanghai People's Press, 1965).

Perkins, D. H., Agricultural Development in China, 1368-1968 (Edinburgh: Edinburgh University Press, 1969).

Peterson, W. J. (ed.), The Cambridge History of China (Cambridge: Cambridge University Press, 2002).

Pomeranz, Kenneth, The Great Divergence, Europe, China and the Making of the Modern World Economy (Princeton: Princeton University Press, 2000).

Rawnsley, G. D. and M. T. Rawnsley (eds.), Political Communications in Greater China (London: RoutledgeCurzon, 2003).

Shi Shenghan, Nongzheng Quanshu Jiaozhu (Annotated Edition of the 'Complete Treatise on Agricultural Administration') (Shanghai: Shanghai Classics Publisher, 1979).

Shi Zhihong, 'Qingdai Nongye Shengchan Zhibiaode Guji' (Estimation of Rural Production Parameters', Zhongguo Jingjishi Yanjiu (Research into Chinese Economic History) 5 (2015), pp. 5-30.

Shi Zhihong, 'Shijiu Shiji Shangbanqide Zhongguo Liangshi Muchanliang Jiqi Zongchanliang Zai Guji' (Re-Estimation of Yields per $M u$ and the Aggregate Food Output in Early Nineteenth Century China), Zhongguo Jingjishi Yanjiu (Research into Chinese Economic History) 3 (2012), pp. 52-66.

Shuo Chen and James Kai-sing Kung, 'Of Maize and Men: The Effect of a New World Crop on Population and Economic Growth in China', Working Paper (Hong Kong University of Science and Technology, 2013).

Skinner, G. W., 'Marketing and Social Structure in Rural China', Journal of Asian Studies, 24 (1964-5), pp. 3-44, 195-228, 363-400. 
Skinner, G. W., 'Sichuan's Population in the Nineteenth Century', Late Imperial China, 8/1 (1987), pp. 1-79.

Skinner, G. W., The City in Late Imperial China (Stanford: Stanford University Press, 1977).

So, K. L., Prosperity, Region, and Institutions in Maritime China, the Fukien Pattern, 946-1368 (Cambridge [MA]: Harvard University Asia Center, 2000).

Song Lian, Yuan Shi (History of the Yuan Dynasty) (1371), in Er-shi-wu Shi (TwentyFive Official Histories) (Shanghai: Shanghai Classics Press, 1986), vol. 9.

Song Yingxing, Tiangong Kaiwu (Exploitation of the Works of Nature) (1637. Reprint. Guangzhou: Guangdong People's Press, 1976).

Spence, J. D., The Search for Modern China, third edition (New York: Norton, 2012).

Stover, L. E. and T. K. Stover, China: an Anthropological Perspective (Pacific Palisades [CA]: Goodyear Publishing Co., 1976).

Tan Qixiang, Jianming Zhongguo Lishi Dituji (Concise Maps of Chinese History) (Beijing: China's Map Press, 1991).

Tian Fang and Chen Yijun, Zhongguo Yimin Shilue (Brief History of Migration in China) (Beijing: Knowledge Press, 1986).

Wang Dezhao, Qingdai Keju Zhidu Yanjiu (Civil Examinations during the Qing Period) (Hong Kong: The Chinese Univerisyt Press, 1982).

Wang Qi, Xu Wenxian Tongkao (Imperially Commissioned Continuation of the Comprehensive Study of Literature) (publisher unknown, 1586).

Wang Zichun and Gao Jianguo, 'Zhongguo Jin 2500 Nianlai Zhiwu Chonghua Lishi Jiluzhi Wuhou Yanjiu' (Patterns of Second Blossoming of Trees for 2,500 Years in Chinese Records). Nongye Kaogu (Agricultural Archaeology), no. 1 (1985), pp. 196-99.

Wang, Feng, James Lee and Cameron Campbell, 'Marital Fertility Control among the Qing Nobility', Population Studies 49/3 (1995), pp. 383-400.

Wang, Yeh-chien, 'Evolution of the Chinese Monetary System, 1644-1850', in Hou Chiming, ed., Modern Chinese Economic History (Taipei: The Institute of Economics, Academia Sinica, 1979), pp. 425-56. 
Wang, Yeh-chien, 'Secular Trends of Rice Prices in the Yangzi Delta, 1638-1935', in Thomas Rawski and Lillian Li, eds., Chinese History in Economic Perspective (Berkley: University of California Press, 1992), pp. 35-68.

Wang, Yejian, The Database of Grain Prices in the Qing Dynasty (Taipei: Institute of Modern History, Academia Sinica, 2013), on line vide: http://ccts.ascc.net/integration.php?lang=en, available on 1 October 2016.

Will, Pierre-Etienne and R. B. Wong, Nourish the People:_the State Civilian Granary System in China, 1650-1850 (Ann Arbor: University of Michigan Center for Chinese Studies, 1991).

Will, Pierre-Etienne, Bureaucracy and Famine in Eighteenth-Century China (Stanford: Stanford University Press, 1990).

Wright, A. F. and Denis Twitchett (eds), Confucian Personalities (Stanford: Stanford University Press, 1962).

Wu Chengming, Zhongguode Xiandaihua: Shichang Yu Shehui (China's Modernisation: the Market and Society) (Beijing: Sanlian Books, 2001).

Wu Hui, Zhongguo Jingjishi Rugan Wentide Jiliang Yanjiu (Quantitative Studies of Chinese Economic History) (Fuzhou: Fujian People’s Press, 2009).

Xian Jinshan, 'Cong Fangzhi Jizai Kan Yumi Zai Woguode Yinjin He Chuanbo' (Adoption and Spread of Maize Seen from Local Gazetteers), Gujin Nongye (Agriculture, Past and Present), 1 (1988), pp. 99-111.

Xiang Huaicheng, Zhongguo Caizheng Tongshi (A General History of Government Finance) (Beijing: China’s Finance Press, 2006).

Xu Guangqi, Nongzheng Quanshu (Complete Treatise on Agricultural Administration (1628. Reprint. Shanghai: Shanghai Classics Press, 1979).

$\mathrm{Xu}$ Xinwu, Jiangnan Tubu Shi (A History of Homemade Cotton Cloth in the Lower Yangtze Delta) (Shanghai: Shanghai Social Sciences Press, 1989).

Yao Tinglin, Linian Ji (Personal Annals) (c. 1698. Reprint. Shanghai: Shanghai People's Press, 1982).

Ye Mengzhu, Yueshi Bian (Record of Life-time Experience in Songjiang) (c. 1688. Reprint. Shanghai: Shanghai Classics Press, 1981). 
Yu Yaohua, Zhongguo Jiage Shi (A History of Prices in China) (Beijing: China's Prices Press, 2000).

Yuan Yida and Zhang Cheng, Zhongguo Xingshi Qunti Yichuan He Renkou Fenbu (Chinese Surnames, Group Genetics and Demographic Distribution) (Shanghai: East China Normal University Press, 2002).

Zai Ling, Caoyun Quanshu (Complete Records of Stipend Rice Shipping) (N.d., Reprint. Beijing: Beijing Library Press, no date).

Zhang Haiying, Mingqing Jiangnan Shangpin Liutong Yu Shichang Tixi (Commodity Flows and Market Structure in the Jiangnan Region during the Ming-Qing Period) (Shanghai: East China Normal University Press, 2001).

Zhao Erxun, Qingshi Gao (Draft of the History of the Qing Dynasty) (1927), in Er-shi-wu Shi (Twenty-Five Official Histories) (Shanghai: Shanghai Classics Press, 1986), vols. 11 and 12 .

Zhao Gang and Chen Zhongyi, Zhongguo Tudi Zhidu Shi (A History of Land Ownership in China) (Beijing: New Star Press, 2006).

Zhao Wenlin and Xie Shujun, Zhongguo Renkou Shi (A Demographic History of China) (Beijing: People's Press, 1988).

Zhao Yun, 'Jishu Wucha, Zhemu Jiqi Juli Shuaijian Guilü Yanjiu' (Technical Errors: Land Unit Conversion and the Law of Diminishing Distance), Zhongguo Shehui Jingjishi Yanjiu (Research into Chinese Social and Economic History), 3 (2007), pp. 1-13.

Zheng Xuemeng, Jiang Zhaocheng and Zhang Wenqi, Jianming Zhongguo Jingji Tongshi (A Brief Panorama of Chinese Economic History) (Harbin: Heilongjiang People's Press, 1984). 